San Jose State University

SJSU ScholarWorks

Master's Projects

Master's Theses and Graduate Research

Spring 5-1-2021

\title{
Creating House Sharing Programs Standards-Based Evaluation for House Sharing Programs within California
}

Diem Hoang

San Jose State University

Follow this and additional works at: https://scholarworks.sjsu.edu/etd_projects

Part of the Infrastructure Commons, and the Policy History, Theory, and Methods Commons

\section{Recommended Citation}

Hoang, Diem, "Creating House Sharing Programs Standards-Based Evaluation for House Sharing Programs within California" (2021). Master's Projects. 985.

DOI: https://doi.org/10.31979/etd.2zde-ku2a

https://scholarworks.sjsu.edu/etd_projects/985

This Master's Project is brought to you for free and open access by the Master's Theses and Graduate Research at SJSU ScholarWorks. It has been accepted for inclusion in Master's Projects by an authorized administrator of SJSU ScholarWorks. For more information, please contact scholarworks@sjsu.edu. 


\title{
Creating House Sharing Programs
}

Standards-Based Evaluation for House Sharing Programs within California

By

\section{Diem Hoang}

\author{
A Thesis Quality Research Project \\ Submitted in Partial Fulfillment \\ of the \\ Requirements for the \\ Master's Degree \\ in \\ PUBLIC ADMINISTRATION
}

Prof. Frances Edwards, Ph.D.

Adviser

The Graduate School

San Jose State University

May 2021 


\section{Table of Contents}

\section{Creating House Sharing Programs: Standards-Based Evaluation for House Sharing}

Programs within California ......................................................................................................... 5

Increased Housing Cost and Rising Housing Financial Burdens on Families ............................ 5

Baby Boomers Are Aging and Homeownership Demographics. .............................................. 7

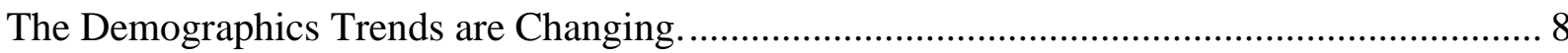

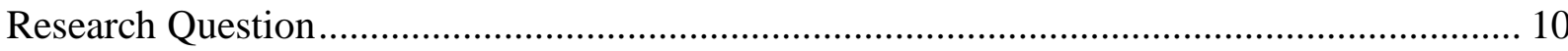

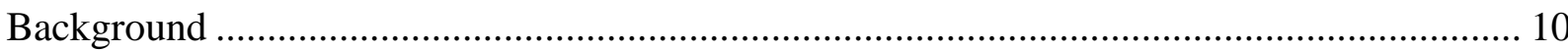

History of National Shared Housing Resource Center........................................................... 11

Literature Review ............................................................................................................................................ 13

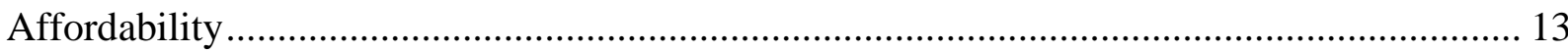

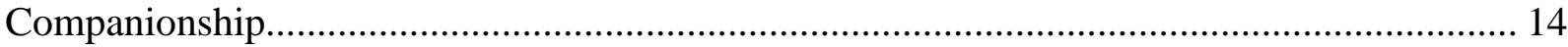

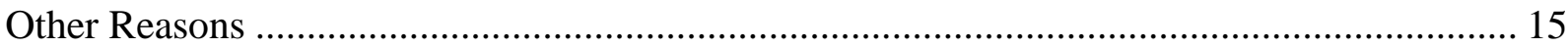

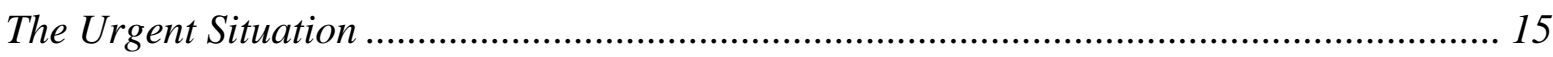

The Opportunity to Live in a Better Neighborhood......................................................... 15

The Social Support................................................................................................... 15

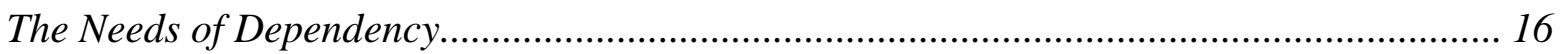

House Sharing Effects on Participants' Physical, Psychological, Social, and Economic Health

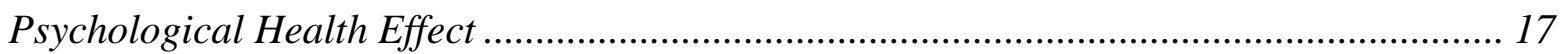

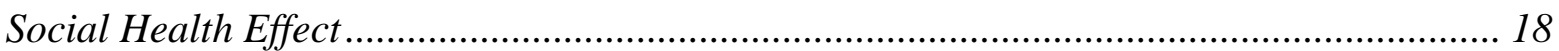

Economic Health Effect .................................................................................... 18

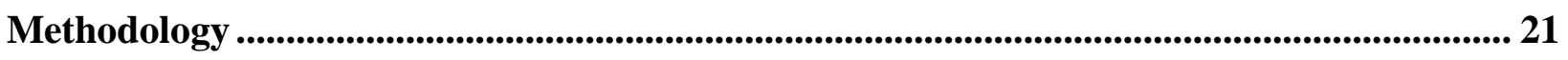

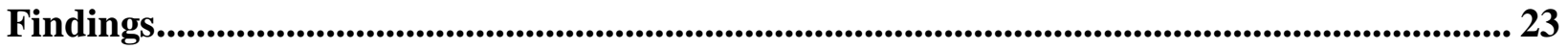

The Inception of House Sharing Programs ...................................................................... 24

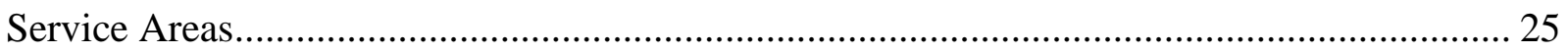

The Number of Successful House Matches and the Average Duration of Matches ................. 29

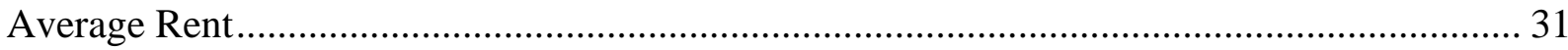

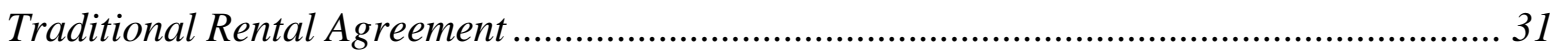

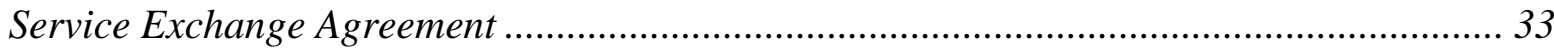

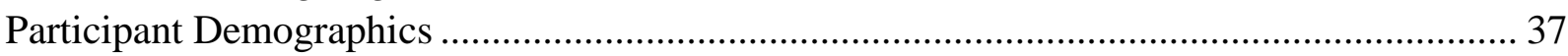

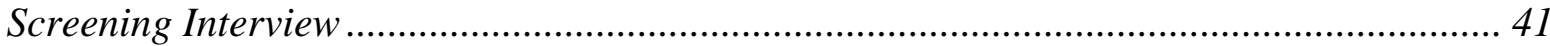

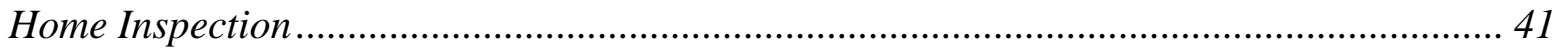

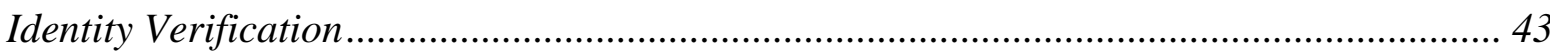

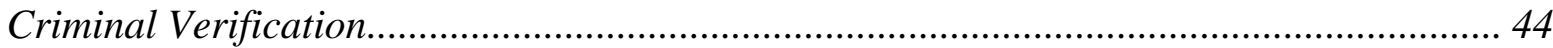

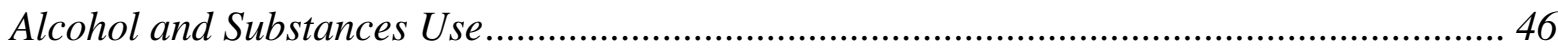

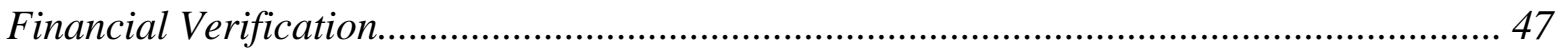

Health Check ................................................................................................... 48 


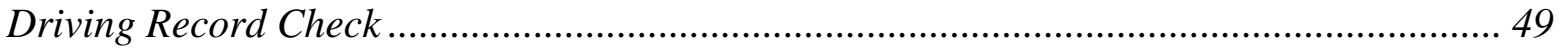

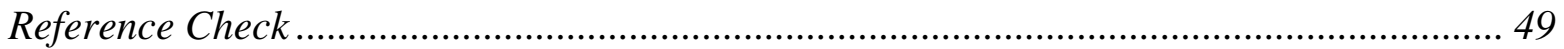

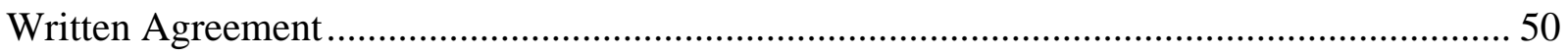

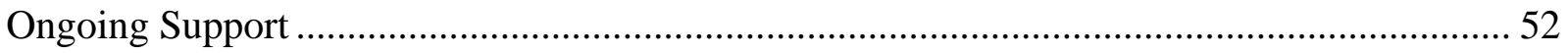

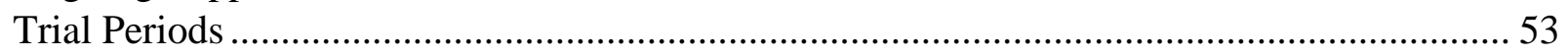

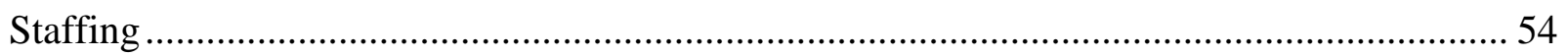

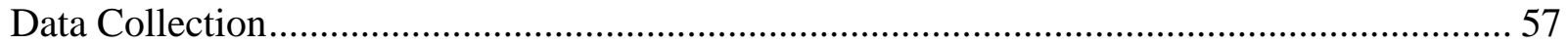

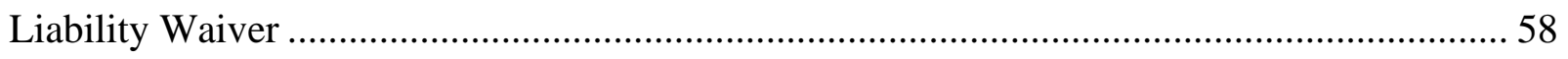

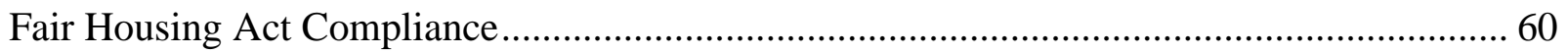

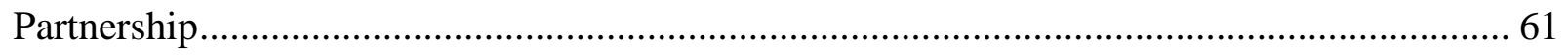

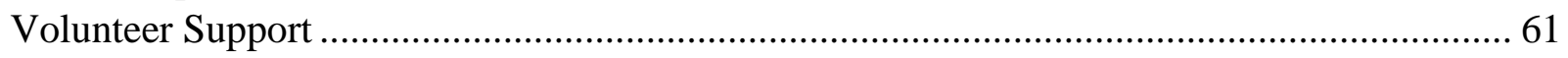

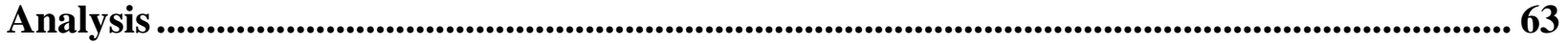

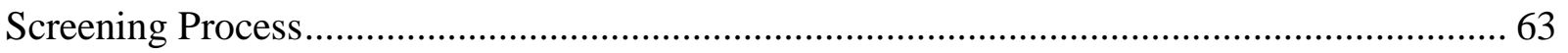

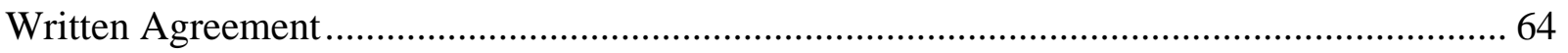

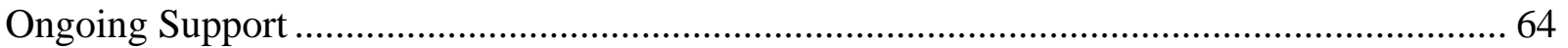

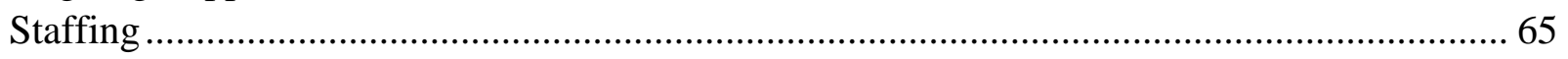

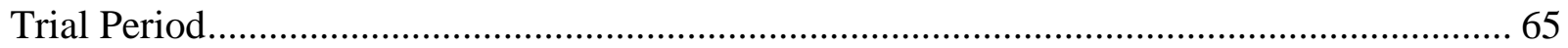

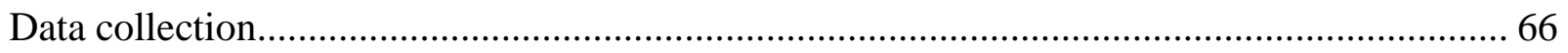

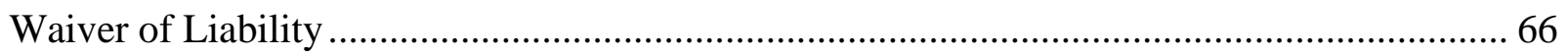

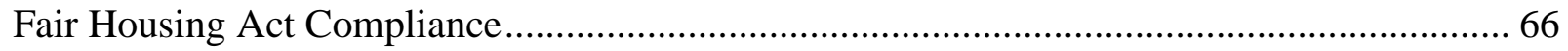

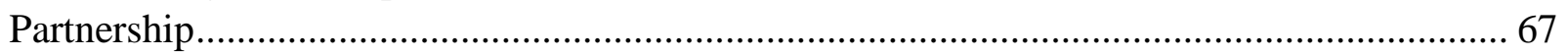

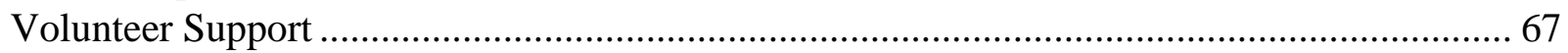

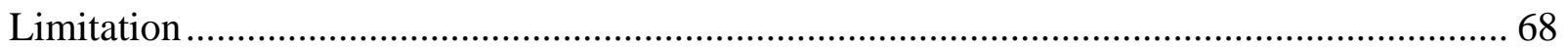

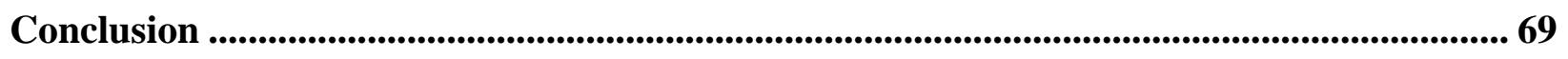

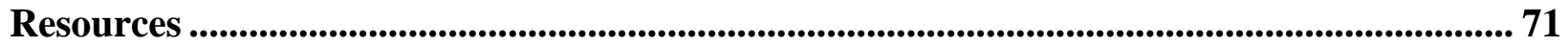




\section{List of Tables}

Table 1: The Inception Dates and Service Areas of each program........................................26

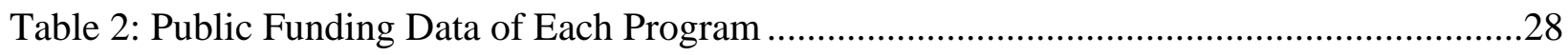

Table 3: The Number of Successful House Matches, the Minimum Duration of a Match, and the Average Duration of a Match of Each Program ....................................................................30

Table 4: The Saving Amount Between a House Sharing Program Versus HUD FY21 ................32

Table 5: Covia’s Monthly Rent for Traditional Rental and Service Exchange Agreement ..........34

Table 6: SHARE Sonoma Definition of Triage Levels. .........................................................35

Table 7: Information of a Traditional Rental, Full-service, and Partial-service Exchange

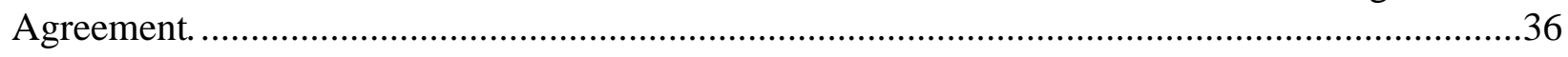

Table 8: Participant Demographics of Each Program.............................................................38

Table 9: House Sharing Hypothetical Criteria of Success of Each Program.............................40

Table 10: Staffing Data of Each Program...........................................................................56 


\section{Creating House Sharing Programs: Standards-Based Evaluation for House Sharing Programs within California}

For the last decade, affordable housing has been an issue for low-income residents of California. Rising construction costs, limited housing supply, and limited budgets to build or preserve affordable housing are all factors that affect the housing crisis. In addition, while the affordability crisis that makes other population struggle in meeting housing demand, the senior population in California, specifically, the number of older adults who lives alone or has no relatives, is increasing (Beck and Johnson, 2015). Seniors want to stay in their homes as long as they can, but they often struggle with housing cost, feel isolated, or need help with housework. For the first time, the number of older adults is expected to be higher than that of children by 2035. Furthermore, there is an increasing number of single households and single parents compared to the 1950s. The U.S demographics are changing. Due to these problems, public managers have been forced to create innovative solutions to provide additional affordable housing units to low-income populations and to create communities that are livable for all ages (AARP, 2019). This research is focused on house sharing programs that can address both problems. These programs have the potential to increase the number of affordable housing units for low-income populations as well as create opportunities for seniors to live better.

\section{Increased Housing Cost and Rising Housing Financial Burdens on Families}

In the last decade, housing affordability has been an increasing issue in California. California has the second-highest two-bedroom apartment rents in the United States (Out of Reach, 2020). The Department of Housing and Urban Development (HUD) has various metrics for defining a housing cost burden on families. They define housing costs as affordable when a household spends a maximum of $30 \%$ of their income on housing costs and utilities. Housing is considered 
a low-level burden on a family when they spend 30 to $50 \%$ of their income on it. Households that spend more than $50 \%$ of their income on housing have a severe housing cost burden. Households that are unable to afford housing might be forced to reduce their spending on their basic needs such as food, clothing, medical care, and transportation (Rental Burden, 2020).

San Jose is an example of this unaffordable housing crisis. The average rent for a onebedroom apartment in San Jose continues to increase year after year. From 2010 to 2016, the rent increased 70\% (City of San Jose, 2019), because the number of jobs added in Bay Area counties is much higher than the number of housing units that has been built since 2010 (Karlinsky et al., 2017). However, the salary of a working family has not increased as much as the rent. The affordable housing supply cannot keep up with the demand, and landlords take advantage of this situation with overpriced rent.

Public managers strive to find ways to solve the affordability situation to help people with housing cost burdens, but they still struggle to solve the situation. For example, from 1999 to 2014, the Bay Area could only issue permits for "35 percent of the units required to meet the needs of vulnerable population such as low-income families, seniors and the homeless" (Metropolitan Transportation Commission \& Association of Bay Area Governments, 2017, p. 10). There are still 100,000 affordable units that need to be built (Metropolitan Transportation Commission \& Association of Bay Area Governments, 2017). Housing is out of reach for these low-income populations, and public managers still have not found a solution. As a result, house sharing has been viewed as a common method to solve affordability issues (Home Sharing, 2016). 


\section{Baby Boomers Are Aging and Homeownership Demographics.}

Baby Boomers are those who are born between 1946 and 1964, after World War II. Nationwide, the population of Baby Boomers who are 65 years old and above has increased 34 percent since 2010 (America Count Staff, 2019). More specifically, in the Bay Area, the percentage of residents who are 65 years old and above is projected to increase from $12 \%$ to $22 \%$ percent from 2010 to 2040 (MTC \& ABAG, 2013). In addition, 86\% of American seniors prefer to stay in their home and their current communities for as long as they are able to, an action also called aging in place, according to an AARP survey (AARP,2019). They prefer to age in place because it might not only be a less expensive option compared to living in a nursing home (where the average cost is $\$ 10,646 /$ month) or an assisted living facility (where the median rent is $\$ 4,500 /$ month) in California but also allows them to be independent in their homes and enjoy the familiarity of the communities that they have been living in for many years (Genworth, 2019). However, the majority of American homes are not set up for Baby Boomers to age in place (AARP,2019). Therefore, these seniors require a solution that assists them with "physical and cognitive abilities" when they grow older (AARP, 2019, p.11). In addition, age-friendly counties or cities have been found to be a vital factor for seniors' daily life (Versey, et.al., 2019).

According to the Legislative Analyst's Office, Baby Boomers are more likely to own a home compared to younger generations. In 2011, 80\% of 65-year-old and above Americans owned homes, but only $66 \%$ of all age populations did due to affordability issues mentioned above (ALA, 2012). On the other hand, most of the assets owned by the majority of low-income Baby Boomers are tied to their houses. One of the reasons is that Baby Boomers took out equity from their homes during the economic boom in the early 2000s. As a result, $41 \%$ of Baby Boomers still have a mortgage on their homes as of 2016. Therefore, even though the number of 
older adults who own homes is higher than those who rent, they still have a higher monetary burden, especially ones who have mortgage, according to the Federal Reserve Board, 2016 Survey of Consumer Finance (Joint Center for Housing Studies of Harvard University, 2018). These senior homeowners need a solution that can help them cover their mortgage, housing costs, and necessary expenses, or have extra income as they age.

The cost burden on housing is even higher for seniors who rent. Baby Boomers' income tends to reduce as they grow older. The main source of income for seniors is social security; however, between 2006 and 2016, social security income only increased six percent while the median rent for these seniors increased sixteen percent. However, the federal funding Section 202, Supportive Housing for the Elderly Program, has been reduced in recent years. Since 2012, there have been no new construction projects funded through Section 202 because current funding is only enough for maintenance of existing supportive housing units and administrative costs (Joint Center for Housing Studies of Harvard University, 2018). Other funds that help seniors to stay longer in their homes have also been reduced. As a result, the need for lowincome housing and other social services outnumbers the resources that public funding can provide (Perspective on, 2016).

\section{The Demographics Trends are Changing.}

In 1950, after World War II, 43\% of U.S. households were nuclear families, or families consisting of two parents and their children (AARP, 2019). Since then, this number has decreased to $20 \%$. Today, there are more adults who live alone or with relatives and housemates than there are nuclear families. This group made up almost 50\% of U.S. households in the mid2010s. As life expectancy increases, there are twice as many elderly people who live alone and have no siblings or children in 2020 as there were in 1990 (ALA, 2012). In addition, there has 
been an increase in the number of single-parent households. The growing number of single older adults is caused by the increasing divorce rate and the proportion of women who outlive their spouses. Single-person households represent almost 30\% of America's households. However, only $11.63 \%$ are living in one-bedroom apartments. The current housing units were built in response to the demographics after World War II. As a result, the number of two bedrooms and three bedrooms apartments is much higher than one-bedroom apartments, $26.54 \%$ and $39.82 \%$, respectively. There is a mismatch between the current housing units' stock and the demographics (AARP, 2019). This contributes to the over-housed situation of $20 \%$ of American households (Leonard, 1999).

House sharing has been seen as an opportunity to utilize extra rooms in existing homes owned by seniors in order to help other citizens, such as students or working-age groups, while also providing extra income for homeowners and helping seniors live longer in their homes (Airbnb, 2016) (ALA, 2019).

The majority of non-profit house sharing programs participate in the National House Sharing Resource Center, a network of the main non-profit house sharing programs in the United States. Currently, there are 11 independent California non-profit programs on this network. The majority of house sharing programs are funded either by a local or federal government, or through private donations.

This research compared various house sharing programs in the National House Sharing Resource Center that are approved by California counties and cities and operated through nonprofit agencies with standard metrics published by Affordable Living for the Aging (ALA). The objective was to determine the most successful practices. This research paper used the 
standard metrics that were published in ALA to compare and analyze 11 non-profit organization operations with the expectations that were set by the publication.

The purpose of this research is to provide samples, understanding, and procedures to nonprofit agencies that operate house sharing programs through California counties and cities as they start new programs or improve their current programs. This research also attempts to inform readers of the advantages of house sharing programs and evaluate metrics of success among current programs to provide successful guidance for existing or new programs.

\section{Research Question}

What best practices from the Affordable Living for the Aging guide are used by 11 selected California house sharing agencies? Which practices are associated with the most successful placements?

\section{Background}

According to the US Department of Housing and Urban Development, "House sharing is a living arrangement in which two or more unrelated people share a house or apartment" (Home Sharing, 2016, p.1). House sharing is commonly known as home sharing. Each resident usually has their own bedroom, however, common areas such as kitchen, laundry, living room, and bathroom might be shared (ALA, 2012). A house sharing program provides a service that helps match a person who has an extra room or separate unit available (a provider) with a person who is looking for a place to live (a seeker) (Home Sharing, 2016). In general, house sharing is a type of permanent housing (Benton, 2014). The overall benefit of house sharing is that it is feasible, and it is a cheaper option than other types of housings (e.g., apartments or roommates) (Benton, 2014). 
House sharing program stakeholders are renters and landlords (Benton, 2014). In general, the programs use the word "seekers" for house sharing renters and "providers" for landlords. House providers are usually homeowners or leaseholders who have an extra room or two in their house and need extra income or support, such as helping with errands. Often, house providers are seniors who want to rent out an extra bedroom in their residence (City of San Carlos, 2016). House seekers are those who are "looking for a place to live" (Home Sharing, 2016). Singles, "families with children living together, homeless families, veterans, youths," and seniors are house sharing seekers (Benton, 2014, p.10). In general, there is no age restriction for both house

providers and seekers. According to affordablehousetips.com, a match is often successful when a home seeker is a college student that looks for a quiet place to study.

A few examples of house sharing include house sharing with peers, such as two unrelated young professionals share a house in the Bay Area, two divorced single parents who live with their own children share a townhouse, a few farm workers share a one-bedroom apartment or intergeneration house (Ahrentzen, 2003). Many agencies that advocate for senior health consider house sharing as an option to help seniors with extra income and engage with communities to have an easier and more fulfilled life.

\section{History of National Shared Housing Resource Center}

Maggie Khun experienced discrimination by being forced to retire at age 65. As a result, she founded the Grey Panthers, an organization that advocates for elderly issues such as affordable housing and age discrimination in 1970. She is a founder of the first house sharing program in the United States. Her mission is to help older people take control of their lives and focus on what they believe. After receiving the benefits of house sharing in her own home, Kuhn founded the National Shared Housing Resource Center in 1980. This organization provides opportunities 
for seniors to continue to engage with society instead of being alone and forgotten (About National Shared Housing Resource Center, 2020)

For public managers, house sharing is a creative way to bring additional affordable housing options when local budgets are reduced to low-income seniors and people who need affordable housing. It is a cheaper alternative for local governments compared to building new affordable housing units for these vulnerable populations. Maximizing the existing housing stock, "neighborhood stabilization", and savings to the healthcare system are some of the "public benefits at a community level" for house sharing (ALA, 2012). 


\section{Literature Review}

There has been a lot of research about house sharing all across the world. Earlier literature examined the impact of house sharing on participants as well as communities in terms of social and financial benefits. Literature before 2000s viewed house sharing, called "doubling up", as a temporary housing solution and a negative result from high housing cost and inadequate income. The term "double up" has been used in a negative sense because of cultural bias (Ahrentzen, 2003). Today, people of all ages are in house sharing situations longer. The trend is to no longer consider house sharing as a temporary solution but as a long-term housing solution for all types of people, regardless of age and income. In the age of technology, house sharing is becoming more popular. Housing matches are easier to connect through various housing websites. These websites use algorithms to suggest matches based on information that users enter into their database (Maalsen, 2020). Furthermore, house sharing has been viewed as a necessary method to begin to achieve a more economically, environmentally sustainable, and social type of housing (Yerena, 2019). As a result, recent literature focuses on the process of achieving successful house sharing programs that adapt to new trends and help low-income population or seniors.

Shared housing is when two or more people share a kitchen and bathroom but have their own bedrooms (Clark et al., 2018). House sharing is usually linked to affordable rent but limited privacy (Cho et al., 2020). Ahretzen (2003) shows that there are two factors that motivate people to choose house sharing: financial and non-financial aspects.

\section{Affordability}

Affordability is a financial aspect of house sharing. Many full-time workers cannot afford current housing costs, nor receive enough assistance from government to live alone (Clark et al., 2017). Low-income people who have difficulty in keeping up with their mortgage or paying for their 
own place usually choose house sharing (Ahrentzen, 2003). Young people chose house sharing to overcome their financial constraints (Clark et al.,2018). Shared housing reduces housing costs per capita for participants (Cho et al., 2019). However, Cho et al. (2020) found that young people who chose house sharing for only an affordability reason are likely to have negative experiences because of conflict among residents.

\section{Companionship}

Non-financial aspects can include security, friendship, or companionship. According to a survey of 30 people who have intellectual disabilities, many prefer shared housing They want to socialize with their housemates and receive support from them. In general, these participants feel that they have the privacy they need in their room. However, some participants in this survey wished that they could maintain "a closer relationship with their housemates" (Fisher et al.,2019, p.5). They hope for companionship in house sharing but realize that the relationship might not be formed (Fisher et al., 2019). Furthermore, more than 50\% of seniors reported that house sharing helps them stay active in both physical and mental states. They feel more connected with society and their emotions when they are in house sharing situations (Airbnb, 2016).

In addition to financial and non-financial reasons, demographics and culture might be other reasons that one chooses house sharing. White households tend to participate in house sharing programs less than African American, Hispanic, and other races' households, regardless of their income. Because of cultural differences, Asian and Hispanic families adapt to house sharing that creates a situation where there is a high density of people in a home better than nonHispanic White and African American families (Ahrentzen, 2003). Ahrentzen (2003) brings up an untested hypothesis that certain ethnic groups or households prefer to live in a high-density 
situation that provides them a chance to live in a better neighborhood over living alone in a less desirable neighborhood.

\section{Other Reasons}

Another study of housing experiences for low-income families in Chicago shows that there are four main reasons for house sharing (Ahrentzen, 2003, p.551).

\section{The Urgent Situation}

"The emergency situation and need" is one type of home sharing situation where a participant seeks home share before having an urgent or unexpected situation that forces them to be homeless (Ahrentzen, 2003, p.551). For example, someone who loses their job due to COVID19 and cannot afford full rent would seek house sharing before becoming homeless.

\section{The Opportunity to Live in a Better Neighborhood.}

House sharing gives participants a chance to live in a better neighborhood. The San Jose Giants have a program called the Host Family Program (MILB, 2013). It provides a room in the Bay Area, an expensive region, to young minor league baseball players who live on a small, fixed income salary (Hartman, 2018). In return, the host families receive "season tickets and parking passes" for the San Jose Giants games. They can also attend Giants picnics and other events (Herald, 2016). Talipova et al. (2018) found that young people choose co-living because they want to live in a better environment that can support them with their "purpose or intention" (Talipova et al., 2018, p.5). Co-living or house sharing provides them opportunities for brainstorming new ideas, developing and improving themselves (Talipova et al., 2018).

\section{The Social Support}

The third reason that Ahrentzen listed is "instrumental and emotional support" (Ahrentzen, 2003, page 552). Instrumental refers to items such as financial support, assistance with chores, and 
childcare. Emotional refers to encouragement and companionship. A survey shows that people who are highly educated, earn low to moderate-income, and are interested in the interconnection between "work, friendship, and leisure travel" prefer social benefits over financial benefits of house sharing (Ahrentzen, 2003, p.552). Cho et al (2019) found house sharing could encourage residents' socialization, engage citizens in civic life, and build better communities. These activities lead to improvement in residents' mental health. Therefore, house sharing might reduce the depression risk that comes from loneliness and isolation (Cho et al.,2019)

\section{The Needs of Dependency}

The last reason is dependency. Even though house sharing is for everyone, regardless of their race, age, or income, there is a tremendous amount of literature that highlights the special benefits of house sharing programs for seniors and people with limited mobility. House sharing can apply to limited mobility or senior homeowners who cannot take care of themselves. House sharing allows a senior or limited mobility person to live in his or her house and still get the help that he or she needs (Affordable living for the aging (ALA), 2014).

People with mobility limitations chose house sharing because they want more control of their lives. First, they could save more money on housing costs and choose to live with someone who has similar interests. As a result, they have more control of their financial situation while receiving social support. Second, they could house share with another limited mobility person to combine their social services funding and split the support cost (Fisker et al.,2019). 


\section{House Sharing Effects on Participants' Physical, Psychological, Social, and Economic Health}

Ahrentzen (2003) analyzes four different types of health that are affected by house sharing: physical, psychological, social, and economic health, sometimes negatively.

\section{Physical Health Effect}

A higher rate of asthma, malnutrition, and a high rate of domestic violence are potential negative effects that house sharing participants might encounter (Ahrentzen, 2003). High-density situations may cause lower air quality in a house depending upon the size of a home. Weitzman, Gortmaker, and Sobel (1990) found that African American children tend to have higher rates of asthma due to high-density living situations. A second negative effect on physical health is malnutrition. In addition, even though the majority of house sharing seekers can cook, a few of them report that kitchen access is difficult because they have to ask for permission to cook or they cannot cook at all. Therefore, participants might not cook as much as they want, which can lead to malnutrition. Third, there is an increase in domestic violence due to overcrowding, a theory that Marin brought up in 1999 (Ahrentzen, 2003, p.555).

\section{Psychological Health Effect}

Interpersonal relationships in house sharing can have either positive or negative impact on residents' psychological health (Clark et al., 2017). Home share participants over 70 years old are happier and more energized when they find younger housemates, enjoying not just the financial benefits, a study by Altus and Matthews in 2000 found (Ahrentzen, 2003). On the other hand, the study found that 50 to 69 -year-old home share participants are more interested in the financial benefits. Halperm (1995) found that participants who live in high-density situations might be unhappy at home, which also affects their psychological mood outside their homes, 
such as at work (Ahrentzen, 2003). Thus, Clark et al. (2019) found that in order for residents to harmoniously live together and avoid conflicts, they need to balance their interpersonal relationships.

\section{Social Health Effect}

Shared housing and socialization are interconnected to each other (Bergan, 2019). Shared housing affects social relationships, and social relationships affect the success of house sharing matches (Bergan, 2019). Letiecq, Anderson, and Koblinsky (1998) found that homeless single mothers who live in shared housing receive more social support, such as babysitters, than if they stay in emergency shelters or transitional housing (Ahrentzen, 2003).

In the past, young people viewed house sharing as a temporary situation prior to living alone or with a partner (Health et al., 2018). However, due to the increase in housing cost, it has recently been difficult for one to move out of a house sharing situation that calls for "living at home until marriage" (Health et al., 2018; Maalsen, 2020). Therefore, young people are being forced to live with strangers, and their houses do not feel like homes. Because they lack privacy and security, young people feel at risk of either sexual or physical harassment. As a result, they feel that their mental health is being challenged (Wilkinson and Ortega-Alcazar, 2017). On the other hand, Cho, Woo, and Kim (2019) show that even though shared housing participants in Korea have less privacy, they benefit from the social networking within their houses. As a result, “their risk of social isolation" is reduced (Cho, Woo, Kim, 2019, p.1).

\section{Economic Health Effect}

Both Ahrentzen (2003) and Cho et al. (2020) found that house sharing might improve economic health for people who suffered from severe housing cost burden. House sharing could help young singles to save housing cost money for their future (Cho et al., 2020). In addition, 
"house sharing and child support" could be a factor that improves young mothers' living situations by giving them opportunities to attain more education and have fewer children (Ahrentzen, 2003, p.558). Hemmens and Hoch (1996) showed that house sharing can help balance housing prices by creating additional housing to fulfill the current housing demand (Ahrentzen, 2003).

Recent literature focuses on the components that bring out success in house sharing programs as a method that public managers choose to help prevent and reduce homelessness.

Benton (2014) examined 15 house sharing programs in Massachusetts to provide recommendations. She found that house sharing programs have potential benefits for both participants and for the non-profit agencies that operate the programs. Participants who are in a house sharing situation tend to be either in greater or similar stability compared to independent housing, but may receive lower benefits, such as food stamps or cash assistance. In addition, besides the direct financial benefits to participants, most surveyed non-profit agencies report the cost to facilitate house sharing programs is lower than independent housing that they facilitate. Furthermore, house sharing can create economies of scale when participants can use their savings on housing costs towards other basic needs or higher education (Benton, 2014).

Benton (2014) also recommends methods for non-profit agencies to use for efficient outreach for house sharing. Agencies should highlight both financial and non-financial benefits of house sharing programs. Benton (2014) recommends that agencies should only highlight the benefits of house sharing programs and then let participants decide whether they want to participate, instead of forcing them into house sharing situations. These agencies should introduce shared housing programs to participants as an option in addition to the agencies' other housing programs, such as the Section 8 housing voucher program, or programs for homeowners 
with access and functional needs. When participants have concerns regarding the program, staff should be able to recommend solutions (Benton, 2014).

The shared housing program is considered a feasible approach for agencies to operate. The programs provide cheaper housing options to residents and agencies that operate the program. It is better to implement the program as an expansion for housing options instead of as a replacement for other housing programs. If agencies that choose to facilitate the house sharing program have experience in homeless prevention or rapid rehousing, these agencies have an additional tool to help their participants find permanent housing (Benton, 2014). Rapid rehousing is a type of program that helps homeless people find permanent housing (McDonald, 2018).

Finally, Benton (2014) encourages agencies to collect data that is as detailed as possible so that there is sufficient information to analyze the effectiveness of house-sharing programs (Benton, 2014). Data collection is important because it will bring more information to strengthen the house sharing program, and to interest new funders, as well as policymakers (ALA, 2012). The more data that the agencies collect, the more useful their performance reports will be for future researchers or other parties, to support monitoring and evaluation of the programs (ALA, 2012). 


\section{Methodology}

The methodology of this research paper is a standards-based evaluation. A standard-based evaluation is a type of process evaluation usually encountered in practice rather than in theory. Process evaluation is necessary when agencies need to renew their funding and/or receive reimbursement from "both public and private" third parties. (Sylvia \& Sylvia, 2012, p.73). Its goal is to demonstrate an agency's compliance with an external standard set to achieve the program's objective. A list of criteria, called a standard, is used to determine or evaluate the performance of an agency. A standard can be "historical, comparative, industry-based, or engineered" (Sylvia \& Sylvia, 2012, p.76).

This research analyzed a list of industry-based criteria from Affordable Living for the Aging, a non-profit agency that operates house sharing programs in Los Angeles. These criteria included screening process, written agreement, trial period, ongoing monitoring, staffing, data collection, liability waiver, partnership, and volunteer support. Based on these 10 criteria, 11 California non-profit agencies listed on National Shared Housing Resource Center were evaluated as follows:

- Human Investment Project, Inc. (HIP Housing), San Mateo, CA

- Senior Network Services - Shared Housing Program, Santa Cruz, CA

- Ventura County Area Agency on Aging (VCAAA), Ventura, CA

- Elder Help of San Diego - Homeshare Program, San Diego, CA

- Affordable Living for the Aging (ALA), Los Angeles, CA

- Covia (Home Match SF - Contra Costa County - Marin - and Fremont, CA)

- Shared Housing and Resource Exchange (SHARE) Sonoma County, Sonoma, CA

- Napa Valley Community Housing (NVCH) - Home Sharing Program, Napa, CA 
- Smart Share Housing Solutions, San Luis Obispo, CA

- Catholic Charities of Santa Clara County, Santa Clara, CA

- Home \& Heart, Chico, CA

This paper also examined the amount received by agencies through public funds such as community development block grants (CDBG). In addition, it evaluated the number of house provider applicants, house seekers, matches, and the history of each house sharing program. Data was collected from correspondence with non-profit managers, and also with city and county employees, as well as non-profit and government websites, staff reports, academic papers, and news articles related to house sharing programs. 


\section{Findings}

The research was conducted based on the information of the 11 non-profits listed above. The research found that house sharing can come in multiple forms. There are five main house sharing types that this research found: traditional rental agreement, full-service exchange agreement, partial-services exchange agreement, shared community house, and emergency housing.

A traditional rental agreement is where a house seeker pays a house provider a monthly rental amount in exchange for a room in the house provider's home.

A full-service exchange agreement is where a seeker provides certain household chores to a house provider in exchange for a room in the house provider's home.

A partial-service exchange agreement is where a seeker provides certain household chores to a house provider along with a monthly rental amount in exchange for a room in the house provider's home. The monthly rental amount for a partial-service exchange agreement is less than a traditional rental agreement.

A community house is where a non-profit provides administrative support to homeowners who do not live in their homes. Each house can have multiple beds and each tenant has his contract with homeowners (A. Appleton, personal communication, February 16, 2021).

Emergency housing is where a non-profit utilizes community members' homes to provide temporary and long-term housing to fire victims (SHARE Sonoma County, 2019c).

SHARE Sonoma County is the only non-profit that operates a shared community housing and emergency housing as part of its house sharing program. However, the main focus of this research was on the traditional rental agreement, full-service exchange agreement, and partialservice exchange agreement. 
In order to provide readers with the general knowledge of California house sharing programs listed on the National Shared Housing Exchange website, this research paper collected the following data:

- Year founded

- Service areas

- Public funding

- Number of successful house matches

- Duration of matches

- Average rent

- Participant demographics

Home Match, House Match, and House Sharing have been used interchangeably by the 11 nonprofits above. For consistency, this research paper refers to the program that each non-profit provides as a house sharing program. Each program's community consists of the counties and cities that it serves. Due to limitation in space, data collection is divided into two to three tables per section. The non-profits are shown in the tables below in descending order by population.

\section{The Inception of House Sharing Programs}

Each of the non-profits, except Covia, operates one house sharing program for its community. On the other hand, Covia runs five different programs for five different communities. Accordingly, this section and the services area section of the paper examined the inception date of all fifteen programs. Nine out of these programs were started within the last 10 years, and seven in the last five years. 


\section{Service Areas}

The majority of these programs serve the county in which the non-profit is located. Seven out of the 11 non-profits serve their entire county. The others provide services only to specific areas within their counties that they contract with or receive funding from. For example, the Alameda house-sharing program under Covia only serves the Cities of Fremont, Union City, and Newark (Covia, 2021d). The inception date and service areas of each program are shown in Table 1. 


\section{Table 1}

The Inception Dates and Service Areas of each program

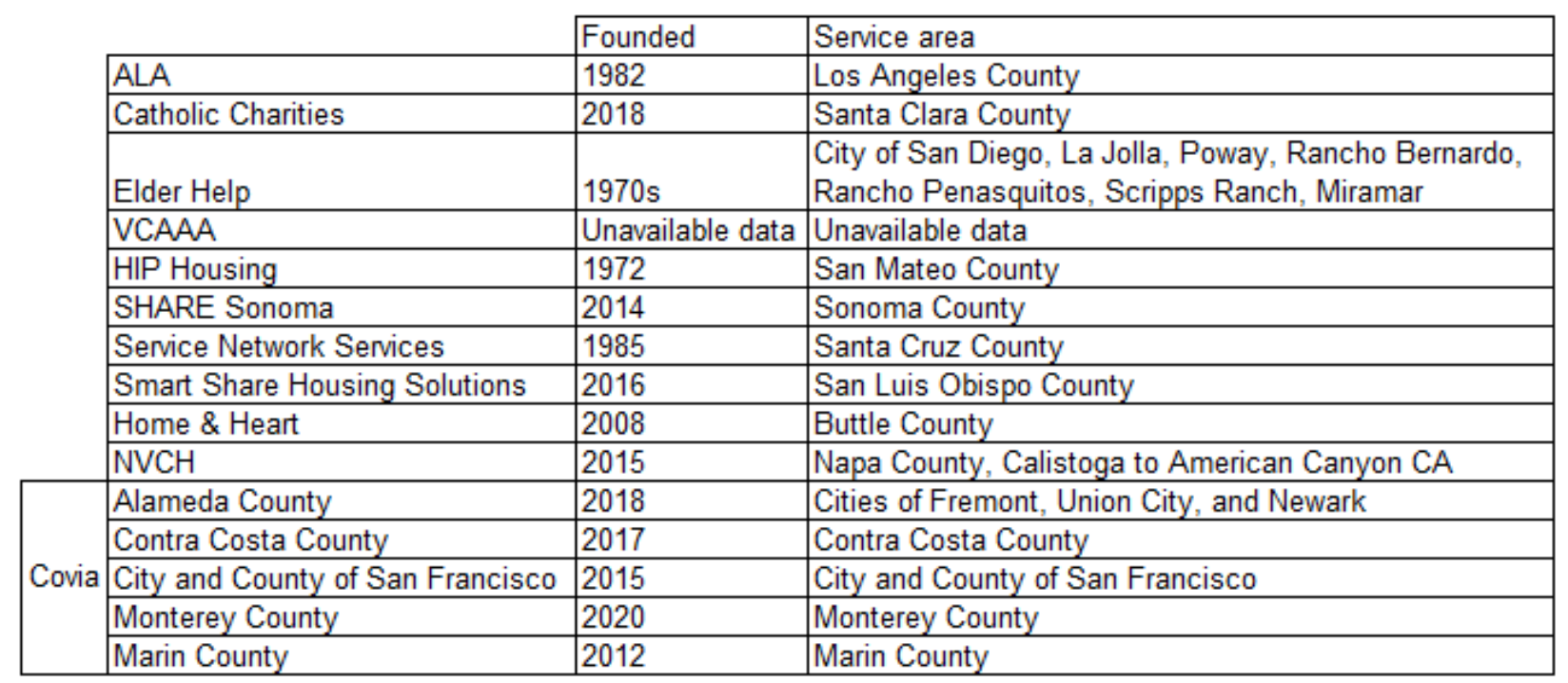

Sources: ALA 2017a.; County of Santa Clara, Office of the County Executive, Office of Supportive Housing, 2018.; Elder Help, 2021a, 2021b.; HIP Housing, 2018a.; SHARE Sonoma. n.d.a; E. Hunton, personal communication, March 1, 2021; Smart Share Housing Solutions, n.d.a; Home \& Heart, 2021a.; S. Schmidt, personal communication, March 4, 2021; B. Cervantes, personal communication, March 4, 2021; Covia, 2021a. 


\section{Public Funding}

House sharing programs receive funding from the city and county in which they operate.

Funding comes from various sources, including federal, state, and local government grants, foundation grants, private donations, and fundraising. Data from HIP Housing and ALA shows that they receive Community Development Block Grants (CDBG), which is a federal grant source funding (L. Fanucchi, personal communication, November 13, 2019; Los Angeles County Development Authority n.d.). Other local government sources include various Grants-in-Aid programs, Homeless Emergency Aid Program (HEAP) grants, and direct contributions from the local government's general fund. Smart Share Housing Solutions receives funding from the Grants-in-Aid program and SHARE Sonoma receives funding from HEAP grants (C. Goyer, personal communication, February 16, 2021; A. Appleton, personal communication, February $10,2021)$.

The funding can be used to pay for either the entirety or a portion of a program's personnel or non-personnel expenses. Personnel expenses include salaries, health insurance, and other fringe benefits. Non-personnel expenses include office rent, background check fees, office supplies, telephone service, equipment lease. For example, the San Diego Housing Commission provides public funding support for Elder Help. Elder Help has decided to allocate the funding for $90 \%$ of one full-time house sharing manager's salary, $37.5 \%$ of one full-time house service coordinator's salary, and $10 \%$ of one full-time marketing staff's salary, as well as a portion of office rent and participants' background check costs. The remainder of its personnel and non personnel expenses come from other sources. Table 2 shows available data regarding public funding for each non-profit. 


\section{Table 2}

Public Funding Data of Each Program

\begin{tabular}{|c|c|}
\hline ALA & CDBG: $\$ 35,465$ \\
\hline Covia & $\begin{array}{l}\text { SF Mayor's Office of Housing Community Development } \\
2015-16 \$ 230,000 \\
2016-17 \$ 235,750 \\
2017-18 \$ 241,644 \\
2018-19 \$ 247,685 \\
2019-20 \$ 253,877 \\
{ }^{*} \text { City of Fremont: } \$ 36,000\end{array}$ \\
\hline Catholic Charities & $\begin{array}{l}\text { Santa Clara County } \\
\text { FY2018: } \$ 172,000 \text { (starting 4/3/2018) } \\
\text { FY2019: } \$ 664,000 \\
\text { FY2020: } \$ 664,000\end{array}$ \\
\hline Elder Help & $\begin{array}{l}\text { San Diego Housing Commission } \\
\text { FY2020: } \$ 65,000\end{array}$ \\
\hline VCAAA & unavailable data \\
\hline HIP Housing & $\$ 1,000,000$ from San Mateo County and other grants \& donation \\
\hline SHARE Sonoma County & $\begin{array}{l}\text { Sonoma County Community Development Commission } \\
\text { - FY19-20: } \$ 185,000 \text { to Sonoma County Home Share Program } \\
\text { - FY19-20: } \$ 106,000 \text { to Share Sonoma Valley } \\
\text { - FY20-21: } \$ 202,352 \text { to Sonoma County Home Share Program } \\
\text { *part of the funding source is from HEAP }\end{array}$ \\
\hline Senior Network Services & $\begin{array}{l}\text { FY2021 } \\
\text { Santa Cruz County: } \$ 20,000 \\
\text { City of Santa Cruz: } \$ 15,000 B\end{array}$ \\
\hline Smart Share Housing Solutions & $\begin{array}{l}\text { San Luis Obispo County } \\
\text { FY19-20 } \$ 10,000 \text { from Community Based Organization/ Preventive Health } \\
\text { Grant }\end{array}$ \\
\hline Home \& Heart & unavailable data \\
\hline $\mathrm{NVCH}$ & $\begin{array}{l}\text { City of Napa } \\
\text { FY 19-20: } \$ 45,000\end{array}$ \\
\hline
\end{tabular}

Source: Los Angeles County Development Authority, n.d.; M. King, personal communication, February 1, 2020; R. Lopez, personal communication, January 26, 2021; County of Santa Clara, Office of the County Executive, Office of Supportive Housing, 2018; San Diego Housing Commission, 2019; L. Fanucchi, personal communication, November 13, 2019; Sonoma County Community Development Commission, personal communication, February 25, 2021; B. Willman, personal communication, March 8, 2021; San Luis Obispo County, 2019; Housing Authority of the City of Napa, 2018. 


\section{The Number of Successful House Matches and the Average Duration of Matches}

The number of matches is a hypothetical measure of success that has been used in various research studies (Hagopian, Farrow, and Locke, 2021; Benton, 2014). Ten out of the eleven programs have made this data publicly available. The majority of the non-profits do not have a required minimum time frame that house providers and house seekers need to remain as housemates before counting it as a successful match. The minimum time frame required by the other non-profits ranges from one month to six months. However, the average duration of a match ranges from 2.5 years to 4.5 years, and the longest match reached 13 years.

In Fiscal Year (FY) 19-20, non-profits were not able to pair as many matches as usual due to the COVID-19 pandemic. Elder Help and ALA suspended services for a short amount of time in 2020 and resumed in 2021. Elder Help did not have any new matches in FY19-20. Table 3 shows available data regarding the number of matches and the average duration of matches for each non-profit. 


\section{Table 3}

The Number of Successful House Matches, the Minimum Duration of a Match, and the Average

Duration of a Match of Each Program

\begin{tabular}{|c|c|c|c|}
\hline & $\begin{array}{l}\text { Number of } \\
\text { successful } \\
\text { house matches }\end{array}$ & $\begin{array}{l}\text { Minimum } \\
\text { duration } \\
\text { of a match }\end{array}$ & $\begin{array}{l}\text { Average } \\
\text { Duration } \\
\text { of a match }\end{array}$ \\
\hline ALA & $\begin{array}{l}\text { Around } 1200 \text { matches ( } 2400 \text { people } \\
\text { matches) since inception } \\
30 \text { matches / year on average } \\
\text { Matching services were suspended in } \\
\text { March due to COVID- } 19 \text {. }\end{array}$ & 1 month & 2.5 years \\
\hline Covia & $\begin{array}{l}\text { From } 2016 \text { to Jan } 2021 \\
248 \text { matches }\end{array}$ & $\begin{array}{l}\text { No time } \\
\text { requirement }\end{array}$ & 1 year \\
\hline Catholic Charities & 27 matches as of Sep 2019 & 90 days & $\begin{array}{l}\text { unavailable } \\
\text { data }\end{array}$ \\
\hline Elder Help & $\begin{array}{l}830 \text { matches since inception } 1970 \\
\text { FY 19-20: } 0 \text { matches due to COVID-19 }\end{array}$ & $\begin{array}{l}\text { No time } \\
\text { requirement }\end{array}$ & 4.5 years \\
\hline VCAAA & unavailable data & $\begin{array}{l}\text { unavailable } \\
\text { data }\end{array}$ & $\begin{array}{l}\text { unavailable } \\
\text { data }\end{array}$ \\
\hline HIP Housing & 65,000 matches since inception 1979 & $\begin{array}{l}\text { unavailable } \\
\text { data }\end{array}$ & 3 years \\
\hline SHARE Sonoma County & $\begin{array}{l}\text { 2014-2018: } 300 \text { matches } \\
\text { Average } 100 \text { matches/year } \\
\text { FY 18-19: } 100 \text { matches } \\
\text { FY 19-20:150 matches }\end{array}$ & 6 months & $\begin{array}{l}\text { unavailable } \\
\text { data }\end{array}$ \\
\hline Senior Network Services & $\begin{array}{l}\text { Unavailable data on total matches in } \\
\text { inception } \\
\text { FY 19-20: } 4 \text { matches } \\
\text { 2-8 matches per year }\end{array}$ & $\begin{array}{l}\text { No time } \\
\text { requirement }\end{array}$ & $\begin{array}{l}\text { many } \\
\text { years }\end{array}$ \\
\hline $\begin{array}{l}\text { Smart Share Housing } \\
\text { Solutions }\end{array}$ & $\begin{array}{l}62 \text { matches ( } 120 \text { participants) since } \\
\text { inception as of Dec } 2020\end{array}$ & $\begin{array}{l}\text { unavailable } \\
\text { data }\end{array}$ & 1-4 years \\
\hline Home \& Heart & unavailable data & $\begin{array}{l}\text { unavailable } \\
\text { data }\end{array}$ & $\begin{array}{l}\text { unavailable } \\
\text { data }\end{array}$ \\
\hline $\mathrm{NVCH}$ & $\begin{array}{l}56 \text { matches (122 participants) as of Dec } \\
2020\end{array}$ & 1 month & $\begin{array}{l}\text { unavailable } \\
\text { data }\end{array}$ \\
\hline
\end{tabular}

Sources: M. Hall, personal communication, February 25, 2021; Covia. 2021b; S. Castillo, personal communication, October 31, 2019; R. Strickland, personal communication, March 1, 2021; HIP Housing, 2018a; A. Appleton, personal communication, February 16, 2021; E. Hutton, personal communication, March 1, 2021; Smart Share Housing Solutions, n.d.a; Napa Valley Community Housing, n.d.; Catholic Charities of Santa Clara County, n.d.b; B. Cervantes, personal communication, March 4, 2021 


\section{Average Rent}

Catholic Charities does not have any available data regarding whether it has full-service or partial-service exchange house sharing programs. The non-profit currently maintains information solely regarding the traditional rental house sharing program on its website. The other 10 nonprofits have available data showing that the programs support traditional rental, full-service, and partial-service exchange house sharing programs.

\section{Traditional Rental Agreement}

Based on the data, the calculation shows that the average rent for one-bedroom through a house sharing program is at least 35\% less than the corresponding HUD FY 21 average market rate. Table 4 shows the calculation regarding the percentage and the amount that one would save if he paid rent through a house sharing program versus HUD FY 21 average market rate. 


\section{Table 4}

The Saving Amount Between a House Sharing Program Versus HUD FY21

\begin{tabular}{|c|c|c|c|c|}
\hline & $\begin{array}{l}\text { Rent amount under } \\
\text { Traditional Rental } \\
\text { Agreement }\end{array}$ & $\begin{array}{l}\text { HUD FY } 2021 \\
\text { Market Rate } \\
\text { for } 1 \text { bedroom }\end{array}$ & $\begin{array}{l}\% \text { of } \\
\text { savings } \\
\text { (Calculation) }\end{array}$ & $\begin{array}{l}\text { Amount of } \\
\text { savings } \\
\text { (Calculation) }\end{array}$ \\
\hline ALA & $\$ 600$ & $1,605.00$ & $63 \%$ & $\$ 1,005.00$ \\
\hline Covia & $\$ 700-\$ 1300$ & $\begin{array}{l}\text { SF: } \$ 2,923 \\
\text { Alameda: } \$ 1,934 \\
\text { Contra Costa: } \$ 1,934 \\
\text { Monterey: } \$ 1,466 \\
\text { Marin: } \$ 2,923 \\
\end{array}$ & $55 \%$ & $\$ 600+$ \\
\hline Catholic Charities & Minimum Rent: $\$ 750$ & $2,558.00$ & $67 \%$ & $\$ 1,808.00$ \\
\hline Elder Help & Average Rent: $\$ 650$ & Unavailable data & $\begin{array}{l}\text { Unavailable } \\
\text { data }\end{array}$ & $\begin{array}{l}\text { Unavailable } \\
\text { data }\end{array}$ \\
\hline VCAAA & unavailable data & $1,519.00$ & $67 \%$ & $\$ 1,019.00$ \\
\hline HIP Housing & unavailable data & $2,923.00$ & $79 \%$ & $\$ 2,323.00$ \\
\hline $\begin{array}{l}\text { SHARE Sonoma } \\
\text { County }\end{array}$ & $\$ 400-\$ 1500$ & $1,519.00$ & $37 \%$ & 569.00 \\
\hline $\begin{array}{l}\text { Senior Network } \\
\text { Services }\end{array}$ & Max: $\$ 750$ & $2,292.00$ & $75 \%$ & $\$ \quad 1,542.00$ \\
\hline $\begin{array}{l}\text { Smart Share } \\
\text { Housing } \\
\text { Solutions }\end{array}$ & Average Rent: $\$ 750$ & $1,263.00$ & $45 \%$ & 631.50 \\
\hline Home \& Heart & Average Rent: $\$ 400$ & 904.00 & $56 \%$ & 504.00 \\
\hline $\mathrm{NVCH}$ & $\$ 750-\$ 1,200$ & $1,531.00$ & $36 \%$ & 556.00 \\
\hline
\end{tabular}

Sources: ALA, 2017c; Covia. 2021c; Catholic Charities of Santa Clara County, n.d.c; Elder Help, 2018b; SHARE Sonoma County, 2019d; A. Selva, personal communication, February 16, 2021; Smart Share Housing Solutions, n.d.j.; S. Schmidt, personal communication, March 4, 2021; Napa Valley Community Housing, 2015; US Department of Housing and Urban Development, 2021 


\section{Service Exchange Agreement}

There are two different types of service exchange. A full-service exchange agreement is when a house seeker spends a certain number of hours per week performing services for a house provider in exchange for a free room. Each of the non-profits has its own limit on the number of hours that a house seeker can perform services to receive a free room under a house sharing program. These limits range from 10 to 20 hours per week. Even though the room is free, some nonprofits (e.g., SHARE Sonoma [SHARE Sonoma County, 2019d]) recommend that house seekers pay the utilities in their house sharing agreement. A partial-service exchange agreement is when a house seeker spends a fewer number of hours per week than the full-service exchange to receive a reduction in rent. For example, under ALA full-service exchange, the maximum number of service exchange hours per week that a house seeker can perform services for a free room is 15 hours. The rent corresponds to the number of service exchange hours which is stated in Table 5 (M. Hall, personal communication, February 25, 2021) below. 


\section{Table 5}

Covia's Monthly Rent for Traditional Rental and Service Exchange Agreement

\begin{tabular}{|c|r|l|}
\hline Hours of Assistance Per Week & Monthly Rent & Traditional Rental or Service Exchange \\
\hline 0 & $\$ 600+$ & Traditional Rental Agreement \\
\hline 5 & $\$ 400.00$ & Partial service exchannge \\
\hline 10 & $\$ 200.00$ & Partial service exchannge \\
\hline 15 & \$0 & Full service exchange \\
\hline
\end{tabular}

Note: From M. Hall, personal communication, February 25, 2021.

According to Elder Help, service exchanges under house sharing should not include personal care services such as bathing, dressing, and providing medical services (Elder Help, 2019a). The limit on the number of hours for service exchange under a house sharing program does not include the extra hours that house providers might pay for through In-Home Supportive Services (IHSS) or out of pocket to fulfil their needs. Napa Valley Community Housing (NCVH)'s House Sharing Program is the only program that requires a caregiver permit for a service exchange agreement. SHARE Sonoma has 5 levels of service exchanges that are described in Table 6, “Definition of Triage Levels" (A. Appleton, personal communication, February 16, 2021): 


\section{Table 6}

SHARE Sonoma Definition of Triage Levels

Triage Level of Weekly Services: 5 Days/Week, 3 Hours/Day, 2 Days: No Duties

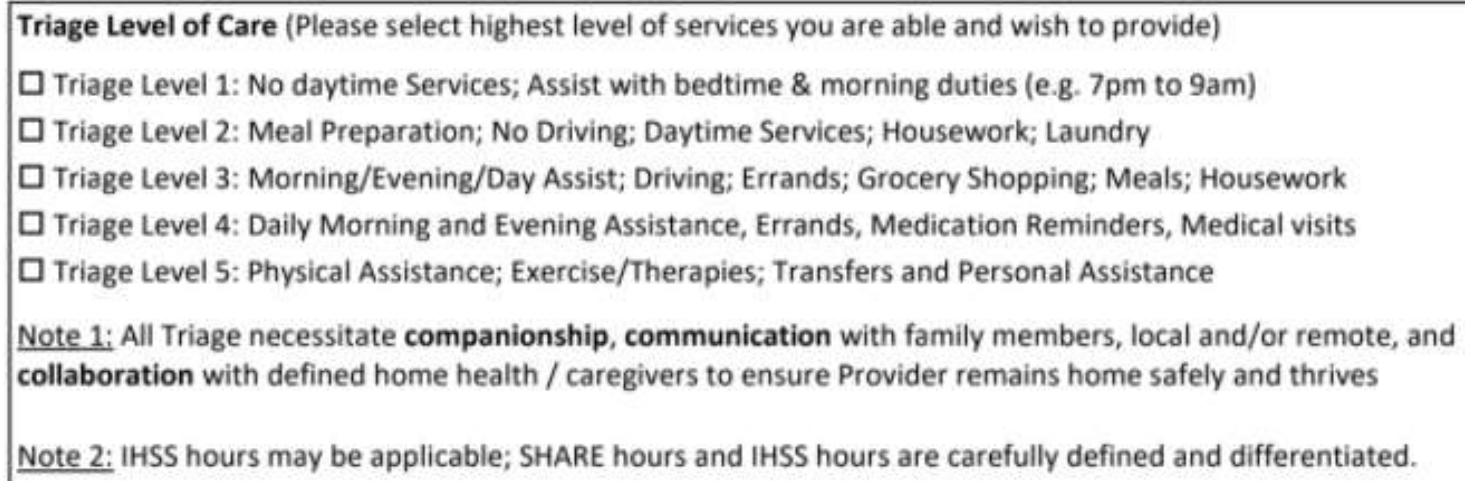

Note: From A. Appleton, personal communication, February 16, 2021. Copyright 2021 by SHARE Sonoma.

In a service exchange agreement, both ALA and Elder Help emphasize that house providers should invite house seekers "over as a guest for either a weekend, a week," or a time that both of them agree on (Elder Help, 2018a, p.8). During this time, the house provider should ask the house seeker to perform the service tasks that the house provider needs (Elder Help, 2018a). The below criteria are listed in Table 7:

- The average rent of a traditional rental, full-service, and partial-service exchange agreement.

- The maximum number of service exchange hours that a house seeker needs to perform for a house provider to receive a free room under a full-service exchange agreement without the possibility of violating tax laws. 


\section{Table 7}

Information of a Traditional Rental, Full-service, and Partial Service Exchange Agreement

\begin{tabular}{|c|c|c|c|}
\hline & $\begin{array}{l}\text { Rent amount } \\
\text { under Traditional } \\
\text { Rental Agreement }\end{array}$ & $\begin{array}{l}\text { Full Services } \\
\text { Exchange } \\
\text { (maximum hours/week) }\end{array}$ & $\begin{array}{l}\text { Partial Services Exchange } \\
\text { (hours/week) }\end{array}$ \\
\hline ALA & $\$ 600$ & 15 hours & $\begin{array}{l}5 \text { hours - } \$ 400 \text { in rent } \\
10 \text { hours }-\$ 200 \text { in rent }\end{array}$ \\
\hline Covia & $\$ 700-\$ 1300$ & Support & $<\$ 800$ \\
\hline $\begin{array}{l}\text { Catholic } \\
\text { Charities }\end{array}$ & $\begin{array}{l}\text { Minimum rent: } \\
\$ 750\end{array}$ & unavailable data & unavailable data \\
\hline Elder Help & $\begin{array}{l}\text { Average rent: } \\
\$ 650\end{array}$ & 20 hours & $<20$ hours \\
\hline VCAAA & unavailable data & Support & Support \\
\hline HIP Housing & unavailable data & Support & Support \\
\hline $\begin{array}{l}\text { SHARE Sonoma } \\
\text { County }\end{array}$ & $\$ 400-\$ 1500$ & $\begin{array}{l}15 \text { hours - Free rent } \\
+\$ 100 \text { utilities }\end{array}$ & $<15$ hours/week: $\$ 300$ in rent \\
\hline $\begin{array}{l}\text { Senior Network } \\
\text { Services }\end{array}$ & Max: $\$ 750$ & $\begin{array}{l}10 \text { hours per week } \\
\text { (domestic services } \\
\text { only, } \\
\text { no personal care) }\end{array}$ & $\begin{array}{l}\text { "\$500 maximum with } 5 \text { hours } \\
\text { of service exchange per } \\
\text { week" }\end{array}$ \\
\hline $\begin{array}{l}\text { Smart Share } \\
\text { Housing } \\
\text { Solutions }\end{array}$ & Avg $\$ 750$ & $\begin{array}{l}15 \text { hours/week + } \\
\$ 150 \text { utilities }\end{array}$ & $\begin{array}{l}8 \text { hours } / \text { week + } \\
\$ 400-\$ 500 / \text { month }\end{array}$ \\
\hline Home \& Heart & Avg $\$ 400$ & Support & Support \\
\hline $\mathrm{NVCH}$ & $\$ 750-\$ 1,200$ & $\begin{array}{l}\text { Support } \\
\text { Caregiver permit } \\
\text { required }\end{array}$ & $\begin{array}{l}\text { Support } \\
\text { Caregiver permit required }\end{array}$ \\
\hline
\end{tabular}

Sources: ALA, 2017c; Covia. 2021c; Catholic Charities of Santa Clara County, n.d.c; Elder Help, 2018b; SHARE Sonoma County, 2019d; A. Selva, personal communication, February 16, 2021; Smart Share Housing Solutions, n.d.j; S. Schmidt, personal communication, March 4, 2021; Napa Valley Community Housing, 2015; M. Hall, personal communication, February 25, 2021; A. Appleton, personal communication, February 16, 2021; A. Selva, personal communication, February 16, 2021; Smart Share Housing Solutions, n.d.j; Home \& Heart, 2021d; Napa Valley Community Housing, 2015 


\section{Participant Demographics}

Some non-profits reported that the average age of house seekers ranges from mid-to-late 50s to early-to-mid 60s and the average age of house providers ranges from 70 to 90 years old.

Furthermore, more than $60 \%$ of house providers and seekers are female. SHARE Sonoma and Senior Network Services require either that house seekers or providers are at least 60 years old or that they would like to live with a senior. This means that having one person who is 60 years old or above in a match is a mandatory requirement for those programs. ALA matches seniors with individuals over 18 years old, according to Los Angeles County Development Authority (Los Angeles County Development Authority, n.d.). Table 8 list each program's participant demographics. 


\section{Table 8}

Participant Demographics of each program

\begin{tabular}{|c|c|c|}
\hline & $\begin{array}{l}\text { House seekers Demographic } \\
\text {-Average (Avg.) age } \\
\text {-\% of female } \\
\text {-the oldest seeker }\end{array}$ & $\begin{array}{l}\text { House providers Demographic } \\
\text {-Average (Avg.) age } \\
\text {-\% of female } \\
\text {-the oldest provider }\end{array}$ \\
\hline ALA & Average age: 65 years old & Average age: 75 years old \\
\hline Covia & $\begin{array}{l}\text { Average age: } 54 \text { years old } \\
66 \% \text { of seekers are female. }\end{array}$ & $\begin{array}{l}\text { Average age: } 73 \text { years old } \\
77 \% \text { of providers are female. }\end{array}$ \\
\hline Catholic Charities & unavailable data & unavailable data \\
\hline Elder Help & Average age: 70 years old & Average age: 80 years old \\
\hline VCAAA & unavailable data & unavailable data \\
\hline HIP Housing & unavailable data & unavailable data \\
\hline SHARE Sonoma County & $\begin{array}{l}\text { Average age: } 58 \text { years old } \\
80 \% \text { of seekers are female. } \\
\text { the oldest seeker: } 96 \text { year old }\end{array}$ & $\begin{array}{l}\text { Average age: } 58 \text { years old } \\
80 \% \text { of providers are female. } \\
\text { the oldest provider: } 96 \text { year old }\end{array}$ \\
\hline Senior Network Services & $\begin{array}{l}\text { Average age: } 60-70 \text { years old } \\
90 \% \text { of seekers are female. }\end{array}$ & $\begin{array}{l}\text { Average age: } 70-90 \text { years old } \\
90 \% \text { of providers are female. }\end{array}$ \\
\hline $\begin{array}{l}\text { Smart Share Housing } \\
\text { Solutions }\end{array}$ & Average age: mid to late 50 's to early 60 's & Average age: early 70 s \\
\hline Home \& Heart & unavailable data & unavailable data \\
\hline $\mathrm{NVCH}$ & $\begin{array}{l}\text { Average age: } 40-80 \text { years old } \\
80 \% \text { of seekers are single females. }\end{array}$ & $\begin{array}{l}\text { Average age: } 40-80 \text { years old } \\
80 \% \text { of providers are single females. }\end{array}$ \\
\hline
\end{tabular}

Sources: M. Hall, personal communication, February 25, 2021; K. Coppock, personal communication, February 28, 2021; R. Strickland, personal communication, March 1, 2021; A. Appleton, personal communication, E. Hutton, personal communication, March 1, 2021; B. Cervantes, personal communication, March 4, 2021; Home \& Heart, 2021d; Napa Valley Community Housing, n.d.; Napa Valley Community Housing, 2015 
In addition, this research paper used the following criteria based on the Affordable Living for the Aging: Strategies for Scaling Shared Housing: Best Practices, Challenges, \& Recommendation (2012) publication as standard evaluations to determine the success of house sharing programs in California cities and counties and to make recommendations on which criteria are the most important contributors for the success of house sharing programs:

- Screening processes

○ Participants' interview

○ Home inspection

○ Background check

- Written agreement

- Ongoing monitoring
- Staffing

- Data collection

- Liability waiver

- Fair Housing Act Compliance

- Partnership

- Volunteer support

- Trial periods

This research highlighted the main differences among the non-profits that have available data on each criterion. Besides the findings for all 11 non-profits, the research also mentioned Home Share Vermont, a publication that is posted as a reference on ALA's website and its publication as a guideline for Do-It-Yourself house sharing. A detailed summary of these criteria is presented in Table 9 


\section{Table 9}

House Sharing Hypothetical Criteria of Success of Each Program

\begin{tabular}{|c|c|c|c|c|c|c|c|c|c|c|c|c|}
\hline & & ALA & Covia & \begin{tabular}{|l|} 
Catholic \\
Charities
\end{tabular} & $\begin{array}{l}\text { Elder } \\
\text { Help }\end{array}$ & VCAAA & $\left|\begin{array}{l}\text { HIP } \\
\text { Housing }\end{array}\right|$ & \begin{tabular}{|l|} 
SHARE \\
Sonoma \\
County
\end{tabular} & \begin{tabular}{|l|} 
Senior \\
Network \\
Services
\end{tabular} & \begin{tabular}{|l|} 
Smart Share \\
Housing \\
Solutions
\end{tabular} & \begin{tabular}{|l} 
Home \\
$\&$ \\
Heart
\end{tabular} & $\mathrm{NVCH}$ \\
\hline & Fees & \begin{tabular}{|l}
$\$ 15$ \\
Background \\
check
\end{tabular} & Free & Free & \begin{tabular}{|l|} 
Free \\
Donation- \\
Based \\
Service
\end{tabular} & $\mathrm{U}$ & Free & $\begin{array}{l}\$ 40 \\
\text { background } \\
\text { check } \\
\text { fee }\end{array}$ & $\begin{array}{l}\$ 62 \\
\text { fingerprint } \\
\text { fee }\end{array}$ & $\begin{array}{l}\$ 500 \\
\text { match fee } \\
\$ 50 \\
\text { application } \\
\text { fee }\end{array}$ & \begin{tabular}{|l|}
$\$ 20$ \\
Background \\
Check Fee
\end{tabular} & U \\
\hline \multirow{18}{*}{ 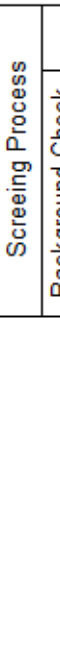 } & Screening Interview & $Y$ & $Y$ & $Y$ & $Y$ & $\mathrm{U}$ & $Y$ & $\mathrm{U}$ & $Y$ & $\mathrm{Y}$ & $\mathrm{Y}$ & $\mathrm{Y}$ \\
\hline & Home Inspection & $\mathrm{Y}$ & $\mathrm{Y}$ & $Y$ & $Y$ & $\mathrm{U}$ & $Y$ & $\mathrm{Y}$ & $Y$ & $Y$ & $Y$ & $\mathrm{Y}$ \\
\hline & Identify & $Y$ & $Y$ & $U$ & $Y$ & $\mathrm{Y}$ & U & $Y$ & U & $\mathrm{Y}$ & $Y$ & $\mathrm{Y}$ \\
\hline & Criminal & $Y$ & Y & $Y$ & Y & $\mathrm{Y}$ & Y & $\mathrm{Y}$ & Y & $\mathrm{Y}$ & $\mathrm{Y}$ & $\mathrm{Y}$ \\
\hline & Alcohol \& Subtances Use & $\mathrm{Y}$ & $\mathrm{Y}$ & $\mathrm{U}$ & $Y$ & Y & $\mathrm{U}$ & Y & $Y$ & $Y$ & $Y$ & $\mathrm{U}$ \\
\hline & Financial Check & $\mathrm{Y}$ & Y & Y & $\mathrm{Y}$ & $\mathrm{N}$ & $\mathrm{Y}$ & $\mathrm{Y}$ & $\mathrm{U}$ & $\mathrm{Y}$ & Y & $\mathrm{Y}$ \\
\hline & Health Check & Y & U & U & Y & $\mathrm{N}$ & $\mathrm{U}$ & Y & $\mathrm{U}$ & $\mathrm{U}$ & U & U \\
\hline & Driving Record Verification & $\mathrm{U}$ & $\mathrm{U}$ & $\mathrm{U}$ & $\mathrm{Y}$ & $\mathrm{U}$ & $\mathrm{U}$ & $\mathrm{U}$ & $\mathrm{U}$ & $\mathrm{Y}$ & $\mathrm{U}$ & $\mathrm{U}$ \\
\hline & References & $Y$ & $Y$ & $Y$ & $Y$ & $\mathrm{Y}$ & $Y$ & $\mathrm{U}$ & $\mathrm{Y}$ & $\mathrm{Y}$ & $Y$ & $\mathrm{Y}$ \\
\hline & Written Agreement & $\mathrm{Y}$ & $\mathrm{Y}$ & $\mathrm{Y}$ & $\mathrm{Y}$ & Y & $\mathrm{Y}$ & $\mathrm{U}$ & $\mathrm{Y}$ & $\mathrm{Y}$ & $\mathrm{Y}$ & Y \\
\hline & Ongoing Support & $Y$ & $Y$ & $Y$ & $Y$ & Y & $Y$ & $Y$ & $Y$ & $Y$ & $Y$ & Y \\
\hline & Trial Period & $\mathrm{Y}$ & $\mathrm{N}$ & $\mathrm{U}$ & $\mathrm{Y}$ & $\mathrm{Y}$ & $\mathrm{N}$ & $\mathrm{U}$ & $\mathrm{U}$ & Y & $\mathrm{Y}$ & $\mathrm{N}$ \\
\hline & Qualitative data collection & U & Y & U & Y & $\mathrm{U}$ & $\mathrm{U}$ & U & $\mathrm{U}$ & Y & U & $\mathrm{U}$ \\
\hline & Waiver of liability & $Y$ & U & $\mathrm{U}$ & Y & Y & $\mathrm{Y}$ & $\mathrm{U}$ & $\mathrm{U}$ & Y & U & Y \\
\hline & Fair Housing Act Compliance & $\mathrm{U}$ & $\mathrm{Y}$ & $\mathrm{U}$ & $\mathrm{Y}$ & Y & $\mathrm{Y}$ & $\mathrm{U}$ & $\mathrm{U}$ & $\mathrm{Y}$ & U & $\mathrm{U}$ \\
\hline & Partnership & $\mathrm{N}$ & $Y$ & $Y$ & $Y$ & $\mathrm{U}$ & $\mathrm{Y}$ & $\mathrm{Y}$ & $\mathrm{Y}$ & $\mathrm{U}$ & $\mathrm{U}$ & $\mathrm{N}$ \\
\hline & Volunteer & $\mathrm{U}$ & U & U & $\mathrm{U}$ & $\mathrm{Y}$ & $\mathrm{Y}$ & $\mathrm{Y}$ & $\mathrm{Y}$ & $\mathrm{U}$ & $\mathrm{U}$ & $\mathrm{U}$ \\
\hline & Total $(Y)$ & 12 & 13 & 7 & 16 & 11 & 11 & 10 & 8 & 15 & 11 & 10 \\
\hline
\end{tabular}

Notes: $\mathrm{Y}=$ Yes - The program adopts the criteria; $\mathrm{N}=$ No - The program does not adopt the criteria; $\mathrm{U}=$ Unavailable data - The program does not have any available data on the criteria.

Sources: ALA, 2017b, 2017c; M. Hall, personal communication, February 25, 2021; SMC Housing Search, 2021; Covia, 2021a, 2021c, 2021d; L. Caldwell, personal communication, October 31, 2019; Catholic Charities of Santa Clara County, n.d.c, n.d.e; Nguyen, 2019; A. Selva, personal communication, February 16, 2021; Elder Help, 2017; Elder Help, 2018a; R. Strickland, personal communication, March 5, 2021; VCAAA, 2016; VCAAA, 2021; HIP Housing, 2018a; SHARE Sonoma County, 2019; Program: SHARE Sonoma County, 2021; Community Foundation Sonoma County, 2019; SHARE Sonoma County, 2019; Senior Network Services, 2020; A. Selva, personal communication, February 16, 2021; C. Goyer, personal communication, February 16, 2021; Share Share Housing Solution, n.d.d, n.d.e, n.d.f, n.d.g; Home \& Heart, 2021d, 2021e; B. Cervantes, personal communication, March 4, 2021; NVCH, 2016 


\section{Screening Processes}

A screening process is the first step when matching house providers to house seekers. The purpose of a screening process is to ensure that participants are eligible for the program. A screening process includes a screening interview, a home inspection, and a background check. Each non-profit agency has its screening process guidelines to interview and verify the background and/or credit checks for house providers and house seekers.

\section{Screening Interview}

During a screening interview, staff learn about participants' communication and interpersonal skills to ensure that they understand, acknowledge, and have a desire to live with others (ALA, 2012). Additionally, a screening interview ensures that both parties have realistic expectations (ALA, 2012). Benton (2014) found that expectations between house providers and seekers need to be clear because many people encounter bad experiences when living with family or friends.

Catholic Charities schedules interviews with participants before having them complete the applications (Catholic Charities of Santa Clara County, n.d.b). ALA requires participants to fill out the applications before scheduling an interview (ALA, 2017c). Participants can download and fill out an online application on VCAAA's, SHARE Sonoma County's, Smart Share Housing Solutions', Home \& Heart's, and NVCH's website and then submit it. Staff from these programs then screen the applications to determine whether house sharing is suitable for each participant.

\section{Home Inspection}

A home inspection or home visits is a process to ensure house providers' residences are safe for house seekers (ALA, 2012). A safe residence is one that is free from pests, termites, and 
environmental hazards. Staff also look for obviously dangerous conditions that might injure tenants (ALA, 2012).

Ten out of 11 non-profits require house providers to have at least a two-bedroomapartment or an extra ADU dwelling unit to participate in house sharing programs. For example, house providers must have an available bedroom when participating in Senior Network Services; house seekers can share a bathroom but "must have access to [the] kitchen area, cupboard, and refrigerator" (B. Cervantes, personal communication, March 4, 2021). NVCH ensures that house seekers have access to the kitchen during its home visitation (B. Cervantes, personal communication, March 4, 2021). On the other hand, HIP Housing allows each individual to "share common areas" and have "their own space" but not necessarily their own bedroom (Kamala, 2019). For example, a house provider of a one-bedroom apartment can have house seekers live in either the bedroom or living room, and can share the rest of the house as common areas (Kamala, 2019).

Once a house provider has the minimum number of bedrooms, staff then visit the home to ensure it is in good condition for house seekers. Information on the duration of a home visit is not available in 10 out of 11 programs. Covia is the only program that reports the duration of a home visit, which takes around 30 mins to 2 hours (Covia, 2021d). During the pandemic, some programs, such as Senior Network Services, facilitated home inspections through Zoom video conferencing or requested pictures from house providers (A. Selva, personal communication, February 16, 2021).

Some programs, such as Senior Network Services or ALA, require house providers' residences to be in good condition to participate in the program (E. Hunton, personal communication, March 1, 2021; M. Hall, personal communication, March 3, 2021). Other 
programs partner with different agencies to bring providers' homes up to code before finding house seekers. Below are examples of the aforementioned house sharing programs.

According to Catholic Charities, if a provider's home is not up to the safety code, the house-sharing program partners with Rebuilding Together Silicon Valley to make the necessary upgrades at no cost for low-income homeowners (Nguyen, 2019).

Elder Help checks to see if its "in-house home, safety, and maintenance team[s]" can assist with the home improvement, otherwise it "refer[s] them out to another program in the area," such as "Jewish Family Services, the CREST program through University of San Diego and Hoarding Solution" (R. Strickland, personal communication, March 5, 2021).

According to SHARE Sonoma, if a homeowner is disabled, and his home has deteriorated, the non-profit can help contact disability legal services for the house provider. The program also refers him to the county house rehabilitation program, which provides up to $\$ 50,000$ in home loans to improve the property's condition before finding house seekers (A. Appleton, personal communication, February 16, 2021).

\section{Background Checks}

House seekers and providers are required to have at least one of the following criterion for their background checks by all 11 non-profits.

\section{Identity Verification}

Most agencies require participants to submit their legal name and a valid photo ID for identity verification purposes. The programs that make the identity verification information publicly available do not verify if participants are U.S. citizens or permanent residents. According to Elder Help, a foreigner can participate in a house sharing program if they provide a valid photo ID “and a Social Security” Number if they have one (Elder Help, 2017, p.6). 


\section{Criminal Verification}

Each agency has its own set of guidelines to accept or deny participants who have criminal records or a history of mental health or substance abuse. Below is a summary of each program's policy.

Smart Share Housing Solutions and HIP Housing check participants’ criminal background history and sex offender records (Smart Share Housing Solutions, n.d.e; HIP Housing, 2018a). Sex offender records are run through the National Sex Offenders Registry (Kamala, 2019). According to HIP Housing, the program runs its limited background search through Superior Court databases, which include San Mateo County and possibly other counties (Kamala, 2019; L. Fanucchi, personal communication, November 13, 2019).

According to Covia, a background check is a soft check that does not have an impact on participants' credit scores. The check pulls “criminal history over the past seven years" and “tenant history such as bankruptcies, liens, judgments, evictions, etc." (Covia, 2021d). Covia may conduct "background search through National or Local Court database records, National Sex Offender databases or a third-party provider of [the program's] choice” (Covia, 2121e, p.9). Participants who are currently on parole or probation, or have an active warrant or felony, must have them discharged before applying for the program. Participants who have a misdemeanor conviction must disclose this to potential housemates (Covia, 2021c).

Senior Network Services disqualifies participants' background checks according to California law requirements (E. Hunton, personal communication, March 1, 2021).

NVCH and ALA disqualify participants if there are any records on their background checks (M. Hall, personal communication, Feb 25, 2021; B. Cervantes, personal communication, March 4, 2021). 
Smart Share Housing Solutions rejects participants who have "an eviction, or convictions for felonies or misdemeanors in the last 7 years" (Smart Share Housing Solutions, n.d.b). Participants who have such records from more than seven years ago are advised to discuss with the program (Smart Share Housing Solutions, n.d.b, Qualification Checklists for Home Providers and Seekers).

Elder Help and VCAAA requires participants to have a background check with "no convictions of any felony, misdemeanor crimes involving bodily injury, assault, elder abuse, sexual offenses, possession or distribution of an illegal substance, or theft of personal property" (Elder Help, 2019b, p.5). VCAAA, however, mentioned that it can assist these unqualified individuals "in finding community resources" to help them (Ventura County Area Agency of Aging (VCAAA), 2016, p.6).

Depending upon the program, participants may or may not have to pay for background checks. The background check is completely free for participants in Catholic Charities, HIP Housing, and Covia (Catholic Charities, n.d.d; SMC Housing Search, 2021; Covia Home Match Marin, n.d.). Senior Network Services covers participants' background checks but collects $\$ 62$ for house seekers' fingerprint processes (A. Selva, personal communication, February 16, 2021). House seekers are expected to pay a $\$ 15$ non-refundable fee for a background check under the ALA program (ALA, 2017c). Home \& Heart charges $\$ 20$ to process its background check (Home \& Heart, 2021c). Smart Share Housing Solutions requires providers to pay a match fee (up to $\$ 500$ ). The fees go to the agency for providing matching services to house providers. The match fee is paid once house providers and seekers sign the agreement. This match fee is $50 \%$ of the first month's rent of a traditional rental or a partial-service exchange agreement (C. Goyer, personal communication, February 16, 2021). For full-service exchange agreements, there is no 
charge for match fees; however, the providers can donate if they wish. Match fees are waived if the match lasts less than three months (C. Goyer, personal communication, February 16, 2021). Additionally, seekers need to pay $\$ 50$ for application and screening fees under the Smart Share Housing Solutions program (Smart Share Housing Solutions, n.d.g).

\section{Alcohol and Substances Use}

There is available data for eight out of 11 programs regarding the alcohol and substance use policy.

According to Elder Help, participants who have a history of alcohol and substance dependency are not automatically rejected from the program (Elder Help, 2017). These

participants can be admitted under "the discretion of the Home Share Coordinator" (Elder Help, 2017, p.5). Participants must declare that they have been sober for at least a year with one witness who can confirm their sobriety (Elder Help, 2017).

Smart Share Housing Solution requires house providers and seekers who have a history of drug and alcohol dependency to recover from their addictions for at least two years (Smart Share Housing Solutions, n.d.b)

VCAAA disqualifies any participants who currently have "untreated substance abuse problems" (VCAAA, 2016). Participants are required to recover from substance use for at least two years with sufficient documentation (VCAAA, 2016).

Covia requires participants to answer a list of questions regarding participants' use of alcohol and substances on its application (Covia, 2021e, 2021f).

Home \& Heart does not accept participants who have any "substantiated case of abuse of any kind" (Home \& Heart, 2021c, p.2). 


\section{Financial Verification}

The majority of the programs require house seekers but not house providers to provide proof of income before participating in house sharing programs. Below are some examples that highlight the differences in policy for the programs that have available data.

According to Covia, house providers who are behind payment on their mortgage "must work with a HUD-certified housing counselling agency" to avoid foreclosure on their houses and must disclose their mortgage financial status to their potential housemates (Covia, 2015, p.1). House seekers are required to submit their proof of income. Examples of proof of income are the past three months' paystubs, a recent tax return, "a recent documentation of public benefits, and/or Self-Employment Verification Form” (Covia, 2021c).

Smart Share Housing Solution requires house providers to have a good standing mortgage and lease; house seekers need to provide proof of income and 2 to 3 months of bank statements to show their ability to pay rent (Smart Share Housing Solutions. 2020).

According to Elder Help, house seekers are disqualified for the program "if they have had more than three evictions" (Elder Help, 2017, p.5). Also, an eviction must not have occurred within the last two years (Elder Help, 2017). House seekers are required to submit their proof of income (Elder Help, 2019b). Examples of accepted proof of income include two recent bank statements, a paystub, or a "letter from Social Security Administration" (Elder Help, 2019b, p.5).

According to Covia and Catholic Charities, house seekers are required to provide their proof of income. House seekers and providers need to earn less than $80 \%$ of the area median income to participate in Catholic Charities (County of Santa Clara Office of the County Executive Office of Supportive Housing, 2018). For Covia, their incomes cannot exceed 120\% of the area median income (Covia, 2021c). 
VCAAA does not verify participants' income or perform their credit checks (VCAAA, 2016, p.4). The non-profit also notes that it is the participants' responsibility to determine if an individual is a suitable housemate (VCAAA, 2016).

HIP requires participants to submit a "written income verification" (HIP Housing, 2018a, How It Works). However, the non-profit states that the proof of income is only for statistical purposes and will be kept confidential (Kamala, 2019).

SHARE Sonoma County requires participants to submit proof of their income. The research was not able to collect the type of proof that SHARE Sonoma County required (Program: SHARE Sonoma County, 2021).

NVCH's financial checklist for house seekers includes three recent paystubs or three recent bank statements if they are self-employed (NVCH, 2016).

ALA requires participants to show proof that their income is at least $\$ 1,200$ per month (ALA, 2017c).

There was no public data found regarding participant's financial verification on Senior Network Service.

\section{Health Check}

A health check is to ensure that house providers and seekers can take care of themselves mentally and physically.

Elder Help is the only one out of 11 non-profits that requires house providers to supply the information of their health providers "including physician, psychiatrist, social worker, or therapist" for medical reports (Elder Help, 2019b, p.5). House providers need to complete health screening forms before having a phone interview, to assure their health is qualified for the program (Elder Help, 2019b). 
VCAAA does not verify participants' "physical and mental health status" (VCAAA, 2016, p.4). The non-profit also notes that it is the responsibility of participants to determine if an individual is a suitable housemate (VCAAA, 2016).

ALA requires participants to sign a medical release form during its enrollment process (ALA, 2017c). There is no other available data regarding that process on ALA's website.

\section{Driving Record Check}

Elder Help and Smart Share Housing Solutions report available data regarding driving record checks for participants. According to Elder Help, driving is usually required in a service exchange agreement. If driving is required, participants need to submit their driver licenses, with no DUI records in the last two years, and proof of current California vehicle insurance and registration, "(if the applicant has an automobile)" (Elder Help, 2017, p.6). Furthermore, a DMV conviction, other than a DUI conviction, can also impact participants' eligibility depending on the Home Share Coordinator's decision (Elder Help, 2017). Smart Share Housing Solutions mentions on its website that all participants are required to have their driving record checked (Smart Share Housing Solutions, n.d.d).

\section{Reference Check}

A reference check is another type of background check that most programs require from participants. Most programs require at least three references that either the non-profits' staff or house providers can call to verify. Smart Share Housing Solutions, HIP Housing, Catholic Charities, Home \& Heart, and NVCH require participants to provide three references when applying (Smart Share Housing Solutions, n.d.b; HIP Housing, 2018b; Catholic Charities of Santa Clara County, n.d.c; Home \& Heart, 2021f; Napa Valley Community Housing, 2020). Elder Help requires participants to provide three specific references from their supervisor, 
landlord, and a personal reference who is not related to the participant (Elder Help, 2019b).

SHARE Sonoma County requires references check for individuals who participate in its house sharing program (SHARE Sonoma County, 2019). There is no information regarding the number of references that the non-profit requires.

VCAAA requires four references, which include one employment reference, if possible. These references should be within the last five years. Acceptable references include roommates, landlords, employers, or colleagues. Family members and significant others are non-acceptable references (VCAAA, 2021). VCAAA contacts participants' references "upon receipt of a completed application package" (VCAAA, 2016, p.4).

Based on available data, either the program staff or house providers and house seekers contact each other's references. Participants swap references with each other under the Covia program (Covia, 2021d). An Elder Help coordinator contacts participants' references after the home visit (Elder Help, 2019a). Home \& Heart staff contacts participants' references after collecting participants' photo ID and proof of income (Home \& Heart, 2021e).

\section{Written Agreement}

All of the 11 non-profits suggest that participants should sign a house sharing program agreement to protect the interest of both parties. Participants can use an agency's template or draft their agreements (Benton, 2014). These agreements are necessary when there are conflicts that arise between two parties (ALA, 2012).

According to Covia, house sharing terms and conditions, environment, how day-to-day activities and participants' best practices might be mentioned in the house sharing agreement. Many participants choose month-to-month agreements when they join house sharing programs (Covia, 2021c). 
Elder Help emphasizes the importance of a house sharing agreement because it improves the success rate of a match. The non-profit recommends that the agreement should follow California fair housing laws. The rental agreement usually includes the rent, utilities, and security deposit amount (if applicable), move-in date, and other relevant information such as "house rules and the responsibility of each [house mate]" (Elder Help, 2019b, p. 3). An example of a house seeker's expected responsibilities is to share household chores and to "clean up after themselves" (Elder Help, 2019b, p. 4).

VCAAA recommends that an agreement can include the following items: "rent, service, meals, phone, quiet hours, parking and any other items both parties want to add" (VCAAA, 2016, p.5)

ALA recommends that house sharing agreements specify the notice time that participants need to provide before ending the agreements. The notice time that the participants need to provide before ending the agreements is usually 30-60 days (Home Share Vermont, 2013). Elder Help mentions that providers and the seekers need to give a 60-day and 30-day notice respectively when they want to terminate an over one-year agreement according to the fair housing laws in California (Elder Help, 2017).

Smart Share Housing Solutions provides house providers with a Living Together Agreement template. The template includes rent, utilities, parking, Covid precautious, and household chores. House seekers will pay the deposits and first-month rent after signing the agreement (Smart Share Housing Solutions, n.d.e).

HIP Housing, NVCH, and Home \& Heart assist participants in preparing the agreement "that capture the unique needs of each match" (HIP 2018a; Napa Valley Community Housing, n.d; Home \& Heart, 2021d). Home \& Heat recommends that the agreement include the rent 
amount, "the hours of service provided", and the activities that both parties agree to (Home \& Heart, 2021d, Match Agreement).

\section{Ongoing Support}

Ongoing monitoring helps staff intervene and mediate house sharing participants' issues before it escalates (Home Share Vermont, 2013). Having knowledge about the match, households' family members are found useful in resolving issues between parties (Home Share Vermont, 2013). An example was after HIP Housing Staff of San Mateo County understand the issues between house providers and house seekers the staff was able to recommend housekeepers in this situation and able to preserve the matches (Home Share Vermont, 2013). All of the 11 non-profits provide ongoing monitoring and mediation for their participants.

During the first 90 days, Catholic Charities will check in monthly with participants. The program will continue to check in on occasion for the rest of their house sharing agreement (Catholic Charities of Santa Clara County, n.d.b).

Covia checks in with participants when they move in and after one month. After that, the programs will check in every month; however, participants can contact the non-profit for "any questions or mediation needs" (Covia, 2021d).

Elder Help advises that the first one or two months of the house sharing program is the opportunity for participants to adapt and adjust when first living together. Participants are encouraged to maintain open communication with each other in order to succeed in this program. Participants can request mediation if they cannot resolve their conflicts. The meeting will follow formal mediation steps and be taken at the provider's home. Both house providers and seekers "must agree to meditate before the process can begin" (Elder Help, 2018, p. 10). 
VCAAA will call participants from time to time to check in on the living arrangement. VCAAA advises that participants can call the non-profit anytime if they have any problems (VCAAA, 2016)

HIP House Sharing, SHARE Sonoma, Senior Network Services, Smart Share Housing Solutions, and NVCH also provide follow up support to participants (HIP Housing, 2018a; SHARE Sonoma County, 2019; Senior Network Service, 2020; Smart Share Housing Solutions, n.d.e; Napa Valley Community Housing, 2020).

Home \& Heart also has an emergency fund where they can relocate someone if needed besides following up monthly and providing mediation in case of conflict (Kaenel, 2020).

\section{Trial Periods}

A study found that participants might have different opinions and expectations about shared housing such as their "standard of cleanliness" (Clark et al., 2020, p.5). Therefore, trial periods help both parties understand more about their expectation (Home Share Vermont, 2013). They work well in service exchange agreements because a house seeker would have opportunities to shadow the house provider and understand what he is looking for (Home Share Vermont, 2013).

Benton (2014) recommends that agencies should allow participants 48 hours or more to think about and choose their potential housemates after agencies introduce matches. After choosing the potential housemates, Home Share Vermont (2013) recommends a one- or twoweek trial period for participants. During the trial period, the non-profit advises house providers to not charge rent or utilities to house seekers, and house seekers to not add cable or Internet for their use (Home Share Vermont, 2013). ALA requires all house providers to waive the rent during trial periods and $60 \%$ of ALA's matches join trial periods (M. Hall, personal communication, March 3, 2021) 
According to Elder Help, $90 \%$ of its matches are willing to participate in trial periods. The rent depends upon a house seeker's length of stay. Elder Help reports that some trial period participants have waived the rents, some have charged a small fee for utilities, and "others who have charged a pro-rated amount of rent" (R. Strickland, personal communication, March 5, 2021).

According to SHARE Sonoma County, a trial period of up to 30 days is recommended for a service exchange agreement (SHARE Sonoma County, 2019e).

Smart Share Housing Solutions' first trial period match under its service exchange program has just started. The trial is for two weeks. In this trial, the house seeker still keeps her current housing and does not move in with all her possession. Also, the majority of traditional rental agreement participants' trial period lasts at least one to two nights. There is usually no rent charges and the house seeker does not move in during that time. "During the trial match, the housemates fill out a detailed Living Together Worksheet" which lists the details on housemates' expectations (C. Goyer, personal communication, February 16, 2021).

Catholic Charities and Senior Network Service do not mention trial periods on their websites. Covia does not offer trial periods (K. Coppock, personal communication, February 28, 2021). Even though HIP recommends a trial period, the staff have not seen house providers waive their rent during trial periods. Most of the providers do not participate in trial periods or waive rents in NCVH's program (B. Cervantes, personal communication, March 4, 2021).

\section{Staffing}

ALA (2013) recommends that agencies should establish a staffing level that is sufficient for the amount of funding they receive, the details of their screening process, and the desired 
number of matches they want to achieve. Table 10 lists each programs' estimated personnel based on their applications that are used to apply for public funding. 


\section{Table 10}

Staffing Data of each program

\begin{tabular}{|c|c|}
\hline & Staffing \\
\hline ALA & One employee \\
\hline Covia & $\begin{array}{l}\text { Home Match SF: } \\
\text { 1 Director } \\
\text { 1 Manager of Outreach } \\
\text { 1 Part-time (Intern) }\end{array}$ \\
\hline Catholic Charities & $\begin{array}{l}\text { 1 Program Manager } \\
4 \text { Case Managers } \\
1 \text { Admin Assistant }\end{array}$ \\
\hline Elder Help & $\begin{array}{l}90 \% \text { of } 1 \text { FTE Home Share Manager } \\
37.5 \% \text { of } 1 \text { FTE Housing Service Coordinator } \\
10 \% \text { of } 1 \text { FTE Outreach / Marketing position }\end{array}$ \\
\hline VCAAA & Unavailable data \\
\hline HIP Housing & \begin{tabular}{|l|}
5 Case Managers \\
1 Program Assistant and \\
Volunteers or Interns \\
\end{tabular} \\
\hline SHARE Sonoma & $\begin{array}{l}2 \text { Fulltime employees } \\
2 \text { Parttime employees }\end{array}$ \\
\hline Service Network Services & Two housing counselors (10 hours/week) \\
\hline Smart Share Housing Solutions & $\begin{array}{l}7.5 \% \text { of } 50 \% \text { FTE Executive Director } \\
20 \% \text { of } 80 \% \text { FTE Outreach Director } \\
10 \% \text { of } 80 \% \text { FTE Operations Director }\end{array}$ \\
\hline Home \& Heart & Unavailable data \\
\hline $\mathrm{NVCH}$ & $\begin{array}{l}50 \% \text { of } 100 \% \text { FTE Bilingual Program Coordinator } \\
50 \% \text { of } 10 \% \text { FTE Program Director }\end{array}$ \\
\hline
\end{tabular}

Note: FTE = Full-time employees

Sources: M. Hall, personal communication, February 25, 2021; County of Santa Clara Office of the County Executive Office of Supportive Housing, 2017; San Diego Housing Commission, 2019; County of Santa Clara Office of the County Executive Office of Supportive Housing, 2017; A. Appleton, personal communication, February 16, 2021; E. Hutton, personal communication, March 11, 2021; San Luis Obispo County, 2018; Housing Authority of the City of Napa, 2018 


\section{Data Collection}

According to ALA (2012), data collection regarding the outcomes and client's satisfaction of house sharing programs is important for current and new house sharing programs. Besides defining common metrics that house sharing programs use, data collection can be expanded to other advanced metrics such as the amount of savings in Medical and Medicare, the "reduction in ER visits among certain target populations", the improvement in seniors' health or for individuals with chronic conditions (ALA, 2012, p. 17).

All of the non-profits collect at least one of the following basic metrics including participant demographics, average rent, the average duration of rent, a year-to-date total number of matches, participants' eligibility. However, only Elder Help, Covia, and Smart Share Housing Solutions have available data on other advanced indicators such as public health cost savings or the percentage of participants who are satisfied in the house sharing programs.

Based on the Elder Help survey report in 2019, data collection shows “ $63 \%$ feel less lonely than they used to $89 \%$ feel their quality of life is better

$75 \%$ feel happier than they used to 89\% believe they are able to live more affordably" (Elder Help, 2019a, p.5)

According to the 2020 Covia survey, $100 \%$ of participants would recommend house sharing programs to their relatives and friends, “77\% [felt] less worried about money", and 61\% were able to save $\$ 600$ per month (Covia, 2021b, Home Match Our Impact).

According to the Smart Share Housing Solutions Impact report in 2020, more than $92 \%$ of house sharing participants reported that they live more affordably, $81 \%$ reported their "quality of life is better", and $85 \%$ reported that house sharing program has been a good experience for 
them (Smart Share Housing Solutions, 2020). Participants report that they "[felt] safer, less lonely, happier, [ate] healthier, or [slept] better" (Smart Share Housing Solutions, n.d.c, p. 1). In addition, Smart Share Housing Solutions also compares other quantitative data points, including the dollar amount benefits directly to participants in "rent income and saving vs traditional rent", the increase in average annual income of a house provider, the average dollas amount in rent that a seeker can save, and the current financial benefits to its current matches (Smart Share Housing Solutions, 2020, p.4). Smart Share Housing Solutions reported that by creating 53 affordable and safe homes for participants, it would be able to save more than $\$ 400,000$ per unit when comparing with new construction (Smart Share Housing Solutions, 2020).

\section{Liability Waiver}

ALA (2013) also recommends a few steps to assure agencies comply with laws and regulations when facilitating house sharing programs. Nonprofit agencies advise that house sharing participants sign a release of the organization's liability due to an unexpected event caused by house sharing. Also, house sharing participants choose nonprofit agencies with an assumption that it is safer compared to online services; therefore, they should have their clients acknowledge the limitation of the screening process that the agencies conduct. ALA requires participants to sign the non-profit's waiver of liability regarding the information obtained from their background check (ALA, 2017d).

Elder Help does not have a section that mentions the waiver of the program liability on background check results; however, it notes that the program is not liable for any legal action or related fees regarding the relationship of the participants, such as eviction proceedings (Elder Help, 2017). 
VCAAA provides a non-liability statement to participants as it does not verify participants' income and "physical and mental health status" or perform their credit checks on its house-sharing information booklet (VCAAA, 2016, p.4). The program also notes that the background checks are limited in nature because it only provides the information in the last five or seven years. The non-profit emphasizes that participants are the ones who make the final decisions in choosing their matches (VCAAA, 2016).

HIP housing includes the program limitation and liability waiver in the agreement between the non-profits and its participants (L. Fanucchi, personal communication, October 15, 2020).

Covia does not have information regarding the non-profit's waiver of liability on its website; however, it requires providers to acknowledge the risks that the program might cause. This information is listed under the "Acceptance of Risk" section. The" Acceptance of Risk" advises house providers and seekers about the risks, such as failure to receive rents, financial, psychological problems, or contagious disease, when having housemates (Covia, 2021f).

Smart Share Housing Solutions requires participants to sign documents that release Smart Share Housing Solutions from any liabilities that "could be caused by the negligence of HomeShare SLO” or other reasons on its Home Provider Application (Smart Share Housing Solutions, 2021).

Home \& Heart does not have any information regarding the non-profit's liability waiver or participants' acceptance of risk. Catholic Charities, Share Sonoma County, and Senior Network Services do not have any information regarding the nonprofit's waiver of liability on their websites. 


\section{Fair Housing Act Compliance}

For properties that are less than four units and owner-occupied, the Fair Housing Act does not apply to house providers when choosing their housemates. However, ALA recommended that agencies include nondiscriminatory requirements in their advertising and any postings (ALA, 2012).

Covia provides its non-discriminatory policy on its participant's application (Covia, 2021e, 2021f).

Smart Share Housing Solutions provides a non-discriminatory section according to Fair Housing law on its Home Provider Application and website (Smart Share Housing Solutions, 2021). The non-profit also displays the Equal Opportunity Housing logo on its webpage (Smart Share Housing Solutions, 2021).

Elder Help provides its non-discriminatory policy that complies with Fair Housing Act on its Home Providers and Seekers Application (Elder Help, 2019b).

VCAAA does not mention the Fair Housing Act on its house-sharing information booklet; however, the non-profit notes that the program "does not make any HomeShare decision/referral based on an individual's race, colour, religion, national origin, ancestry, age, gender identity, marital status, sexual preference or handicap status", even though participants can choose their housemates based on their references (VCAAA, 2016, p.4).

HIP housing does not have any available statement regarding the Fair Housing Law Act or non-discrimination policy on its website; however, the logo of Equal Opportunity Housing is displayed on its website (HIP Housing, 2018a) 
Home \& Heart does not include the non-discriminatory requirement on its website and participants' application (Home \& Heart, 2021c). There are no available data regarding the nondiscriminatory requirements on Catholic Charities, NVCH, Senior Network Services, SHARE Sonoma County websites.

\section{Partnership}

By partnering with other programs or non-profits, the non-profits that facilitate house sharing programs can receive additional referrals from other programs. This research only collects the data on the partnership that the non-profit partners with other agencies to bring a provider's home up to code to find a seeker. Details regarding partnership were listed out in the “Home Inspection" section.

\section{Volunteer Support}

ALA (2012) advised that the program can continue to monitor and provide support to the existing participants and does not have to skip onboarding the potential match through the help of volunteers. Volunteers who are shared housing experts are extra resources to help participants find their housing needs and avoid duplicate caseloads (Benton, 2014).

HIP Housing accepts volunteers for House Sharing Outreach Facilitators for its house sharing program. The position is available from Monday through Friday (HIP Housing, 2018b).

SHARE Sonoma receives volunteer help from its house seekers. House seekers bring their skills, such as woodworking or carpentry, to help out in the program (A. Appleton, personal communication, Feb 16, 2021).

According to the 2020 Smart Share Housing Solution Annual Report, the non-profit also facilitated training in Spring 2020 for a group of volunteers that help staff with client intake and 
house-sharing services. Throughout the pandemic, volunteers assisted participants with phone based tasks, while in-person volunteers are on hold (Smart Share Housing Solution, 2020). VCAAA accepts volunteers specifically for its house sharing program through its website (VCAAA, n.d.j).

Catholic Charities does not have a particular volunteer section for its house-sharing program; however, the non-profit has other volunteer opportunities for other programs (Catholic Charities of Santa Clara County, n.d.d).

Elder Help does not currently have volunteer opportunities for its house-sharing program; however, the program accepts in-home help volunteers for other tasks, such as sorting mail, light gardening, and pet care.

Covia also does not have particular volunteer opportunities for its house-sharing program; however, the non-profit currently matches a volunteer with an adult over 60 years old for a one-on-one and weekly visit (Covia, 2021g).

ALA, Senior Network Services, Home \& Heart, Smart Share Housing Solutions, and $\mathrm{NVCH}$ do not have any information regarding the house-sharing program volunteer opportunities on their websites. 


\section{Analysis}

Publicly funded house sharing programs operated by nonprofits are an effort by public officials to reduce and prevent homelessness (City of Redwood City, 2019). Therefore, unlike house sharing apps, such as Craigslist and Air BnB, they give priority to seniors, low-income, and people at risk of homelessness. In addition, the programs generally provide ongoing monitoring as well as mediation for participants when they have conflict; these interventions are not provided by house sharing apps. House sharing programs also provide coordinators to help seniors rent their spare rooms through an easier and simpler process than housing apps. This creates opportunities for them to have income or companionship, or a combination of both. The research collected data from 11 non-profits involving the 10 criteria listed in the ALA publication. Online research and email or phone communications with staff from the non-profits are the main sources of the findings; therefore, some data might not be available to collect.

\section{Screening Process}

The screening process, along with a rigorous background check, is necessary for the safety and confidence of house providers and seekers. Unlike housing apps, such as Craigslist and Air BnB, house sharing programs have their reputations associated with cities or counties (ALA, 2012). Verifying participants' eligibility, facilitating home visits, and checking identification, financial, criminal, and driving records are the first steps to ensuring that both providers and seekers have a general understanding and are comfortable with each other. This process not only builds trust among existing participants but also establishes house sharing programs' reputations and attracts future participants. Some smart practices include asking participants in their applications if they would like to live with a non, light, moderate, or heavy smoker and drinker, as well as ensuring 
house seekers have access to a kitchen during home visits. Non-profits might benefit from adopting such policies, like Covia and NVCH as mentioned in the "Findings" section of "Screening Process."

\section{Written Agreement}

Ten out of 11 non-profits have available data that they use to assist participants in preparing the match agreements. The agreement is a set of rules agreed upon by both house providers and seekers. It establishes the obligations between the two parties. This written agreement lists out the details of the match, including the number of hours of services exchanged, the amount of rent, and the participants' responsibilities to each other. The agreement ensures that participants have the same expectations before becoming housemates, minimizes potential conflicts, and might be used as a legal agreement to settle future disputes based on the terms of the agreement. The language of a traditional rental agreement is different from that of a full-service or partialservice exchange agreement. A smart practice is to include a list of various levels of service exchange that house providers can choose from. Other non-profits might benefit from adopting such a policy, like SHARE Sonoma as mentioned in the "Findings" section of "Average Rent."

\section{Ongoing Support}

All of the 11 non-profits have available data regarding the ongoing support that they provide during a match's duration. Ongoing support is important because it improves existing and future participants' confidence in a program. A smart but uncommon practice is to have an emergency fund to help relocate participants in case of a severe conflict. Other non-profits might benefit from adopting such a policy, like Home \& Heart as mentioned in the "Findings" section of “Ongoing Support." 


\section{Staffing}

Not all programs have available data on the number of staff required. According to Karen Coppock from Covia, staffing is difficult to estimate because its house sharing program can borrow manpower from other programs of the non-profit. Senior Network Services' house sharing program has the lowest number of staff hours and successful matches. HIP Housing is a larger program; therefore, the number of staff that supports the program is higher. A smart practice is to estimate the number of hours needed to administer the house sharing programs. Other non-profits might benefit from adopting such a policy, like Senior Network Services as mentioned in the "Findings" section of "Staffing."

\section{Trial Period}

Depending on the demographics and characteristics of the community, a trial period might be used as a factor to determine the success of a house sharing program. On the one hand, trial periods that waive rent are recommended by non-profits in communities with a higher cost of living, such as the City and County of San Francisco, the San Mateo County, and the Santa Clara County; however, all of the house providers failed to participate in waiving rent during trial periods. For example, Covia does not offer trial periods (K. Coppock, personal communication, February 28, 2021). HIP Housing reports that even though it recommends trial periods to participants, it has not seen any house providers waive rent during their trial periods (L. Fanucchi, personal communication, November 13, 2019). Therefore, a trial period is not an effective criterion for the success of house sharing programs in these communities. On the other hand, a trial period might be considered as an important criterion for other communities, such as Los Angeles and San Diego County. ALA and Elder Help report that $90 \%$ and 60\% of their 
participants participate in trial periods, respectively. Trial periods are important in these communities because they-give participants time to decide if they are suitable for each other. In conclusion, non-profits might adopt a trial period policy depending on the demographics and economy of the community they serve.

\section{Data collection}

All of the 11 non-profits monitor at least one quantitative data metric; however, there are only three non-profits that make their qualitative data metrics available. These non-profits are ALA, Covia, and Elder Help. Smart practices include collecting both quantitative and qualitative data and presenting them on the non-profit impact reports to improve the success of house sharing programs. Other non-profits might benefit from adopting such policies, like ALA, Covia, and Elder Help, as mentioned in the "Findings" section of "Data Collection."

\section{Waiver of Liability}

Six out of 11 non-profits make their liability waiver available. As discussed in the "Findings" section of "Waiver of liability", VCAAA provides its non-liability notice in its house sharing information booklet, and ALA requires participants to acknowledge that they release the nonprofit from all liabilities in a separate section of its background check authorization. A smart practice is to include the non-liability and acceptance of risk statement in the house sharing information booklet, applications, or both. Other non-profits might benefit from adopting such policies, like ALA and Elder Help as mentioned in the "Findings" section of "Waiver of liability."

\section{Fair Housing Act Compliance}

Five out of 11 non-profits make their Fair Housing Compliance non-discriminatory policy and its corresponding logo available. Even though a non-profit is not required to display its non- 
discriminatory policy, a smart practice might be to include a statement of its non-discriminatory policy or to display the Equal Housing Opportunities logo on its website. Other non-profits might benefit from adopting such policies, like Covia, Elder Help, VCAAA, HIP Housing as mentioned in the "Findings" section of "Fair Housing Act Compliance."

\section{Partnership}

Six out of 11 non-profits provide data regarding whether they have partnered up with other agencies to help bring house providers up to code. By partnering with other agencies, the nonprofits provide extra resources and manpower to seniors who haves homes but are unable to renovate them without assistance. This brings opportunities for extra income and companionship to house providers by matching them with house seekers after a renovation of their homes is complete. A smart practice is to partner with other agencies to provide a makeover for the potential house providers' homes that are not in good condition, and then match them with house seekers. Other non-profits might benefit from adopting such a policy, like Catholic Charities, HIP Housing, and Elder Help which adopt that policy as mentioned in the "Findings" section of "Home Inspection."

\section{Volunteer Support}

Four out of 11 non-profits have available data regarding accepting volunteers for particular house sharing programs. Other non-profits do have a general volunteers' section on their website but not particular for house-sharing programs. A smart practice is to provide volunteers opportunities such as to "assist staff in client intake and matching service", particularly in house sharing programs (Smart Share Housing Solutions, 2020, p.18). Other non-profits might benefit from adopting such a policy, like Smart Share Housing Solutions as mentioned in the "Findings" section of "Volunteer Support." 


\section{Limitation}

According to HUD, permanent housing is defined when the duration of a match is at least one year. This time frame might be an important factor when measuring the success of a program by its number of matches. Seven out of 11 non-profits make the required time frame when considering a successful match available. Three out of that seven programs do not impose a minimum time frame when considering a successful match; another three out of seven programs impose less than or equal to three months and the last one has its duration at six months. As a result, the quantitative data for the number of successful matches depends upon another factor: the minimum time requirement of a successful match. Additionally, this research did not collect the private funding amount of those non-profits. The non-profits that receive more funding would have better resources to hire more staff and to collect better data that can lead to developing more successful programs.

In addition, in a standards-based evaluation, standards are ideally judged based on a set of criteria developed by a professional association through a rigorous process (Sylvia \& Sylvia, 2012). This process is referred to as accreditation. The standards on this research are not accredited. These standards are industry-based. They are based on the ALA, a non-profit's publication that provides house sharing services. This publication was written nine years ago, and there has not been a formal review of this set of criteria since then. 


\section{Conclusion}

A house sharing program is not only a creative solution for an affordable housing option but also provides opportunities for seniors to age in place. Non-profits can provide house matching services for free, charge a small amount to cover the cost of background checks, require a match fee, or operate as a donation-based service. Elder Help and Smart Share Housing Solutions have the most detailed criteria for a successful housing sharing program. All of the eleven non-profits have available data stating that they continue to support the match after house seekers are placed. The most common standards, found in over $80 \%$ of the 11 non-profits' support, are screening interviews, home visitations, criminal checks, income checks, references checks, assisting participants in preparing match agreement, and providing ongoing support throughout a match duration. The least common standards that the non-profits either support or have minimal data are health checks, driving record checks, trial periods, and qualitative data collection. Other unique standards include charging fees to cover the cost of background or fingerprint check, alcohol and substances use declaration, liability waiver, fair housing act compliance disclosure, partner with other agencies to bring house providers up to code, and volunteer' opportunities in house sharing programs.

In conclusion, house sharing programs have become popular in the last 10 years in both traditional rental and service exchange programs. These programs target underserved residents, including seniors and low-income individuals. Covia has increased the number of communities it serves from one community to five communities within the last 10 years. This increment represents the effectiveness of house sharing in a community such as a city or a county. The program acts as a third party to connect residents who are in need. There is a need for a house 
sharing program in each community. The ALA's publication along with this research is a useful document for a non-profit that is looking to start or to improve its house sharing program. 


\section{Resources}

AARP. (2019). Making room: Housing for a changing America.

https://www.aarp.org/content/dam/aarp/livable-communities/livable-

documents/documents-2019/making-room-web-singles-010819.pdf

Affordable Living for The Aging. (2012). Strategies for Scaling Shared Housing: Best practices, Challenges \& Recommendations.

http://www.alaseniorliving.org/files/attachments/HIGH\%20Res\%20ALA\%20Strategic\% 20Guide\%20for\%20website_0.pdf

Affordable Living for The Aging. (2014). How home sharing helps seniors at home.

http://www.alaseniorliving.org/files/attachments/ASA\%202014\%20FINAL\%20for\%20w ebsite2.pdf

Affordable Living for The Aging. (2017a). ALA Story. http://www.alaseniorliving.org/ala-story

Affordable Living for The Aging. (2017b). Shared Housing.

http://www.alaseniorliving.org/shared-housing

Affordable Living for The Aging. (2017c). I am seeking housing.

http://www.alaseniorliving.org/seeking-housing

Affordable Living for The Aging. (2017d). Applicant Authorization.

http://www.alaseniorliving.org/sites/default/files/attachments/Background\%20Check\%20 Authorization.pdf.

Ahrentzen, S. (2003). Double Indemnity or Double Delight? The Health Consequences of Shared Housing and "Doubling Up". Journal of Social Issues. 59(3), 547-568. https://doiorg.libaccess.sjlibrary.org/10.1111/1540-4560.00077 
Airbnb. (2016, November 21). Home sharing: A powerful option to help older Americans stay in their homes. https://www.aarp.org/content/dam/aarp/livable-communities/livabledocuments/documents-2016/Airbnb-HomeSharing-OlderAmericans-Report-11-2016.pdf

Beck, L., Johnson, H., \& Gibson, L. (2015, August). Planning for California's Growing Senior Population. Public Policy Institute of California. https://www.ppic.org/content/pubs/report/R_815LBR.pdf

Benton L. A. (2014, March 15). Creating a Shared Home: Promising Approaches for Using Shared Housing to Prevent and End Homelessness in Massachusetts. https://www.innovations.harvard.edu/sites/default/files/3308562.pdf

Bergan, T. (2019). A Review of Shared Housing, Shared Lives: Everyday Experiences Across The Lifecourse, Edited by Heath, S., Davies, K., Edwards, G. and Scicluna, R.M.. International Journal of Housing Policy. 19(3). 448-450. https://doi.org/10.1080/19491247.2019.1621015

Camhi, T. (2019, October 22). Santa Clara County Plays Matchmaker With House-Sharing Program. KQED. https://www.kqed.org/news/11781257/santa-clara-county-playsmatchmaker-with-house-sharing-program

Catholic Charities of Santa Clara County. (n.d.a). Catholic Charities of Santa Clara County. https://www.catholiccharitiesscc.org/about-us

Catholic Charities of Santa Clara County. (n.d.b). House Sharing Program. How to be a home provider. https://static1.squarespace.com/static/59d3cfe8e5dd5b0acaa2a2b4/t/5d852a01c888787b1 aa914b8/1569008129978/Process+Flow+Graphic-both.pdf. 
Catholic Charities of Santa Clara County. (n.d.c). House Sharing Frequently Asked Questions. https://www.catholiccharitiesscc.org/house-sharing-faq?locale=en.

Catholic Charities of Santa Clara County. (n.d.d). Become a Volunteer. https://www.catholiccharitiesscc.org/volunteer?locale=en.

Catholic Charities of Santa Clara County. (n.d.e). House Sharing Program. https://www.catholiccharitiesscc.org/house-sharing?locale=en.

Cho, G., Woo, A., \& Kim, J. (2019). Shared housing as a potential resource for community building. Cities. 87. 30-38. https://doi.org/10.1016/j.cities.2018.12.019

Cho, G., Woo, A., \& Kim, J. (2020) Is shared housing a viable economic and social housing option for young adults? Willingness to pay for shared housing in Seoul. Cities. 102732. https://doi.org/10.1016/j.cities.2020.102732

City of Redwood City. (2019). FY 2019-2020 Action Plan Community Development Block Grant \& HOME Investment Partnerships Program. https://www.redwoodcity.org/home/showdocument?id=17910

City of San Carlos. (2016). City Hall In Focus: HIP Housing [Video]. https://www.youtube.com/watch?v=eKAyzWo6K_8\&fbclid=IwAR3gg7AEQ3kBaL5Gq 6007zuzJH8TRchBGsxxnmnwYZXOjDNcLKZz9BNq06A

City of San Jose Housing Department. (2019, May 24). Quarterly Average Apartment Rent. [Data Set]. https://data.sanjoseca.gov/dataset/quarterly-average-apartment-rent

City of Santa Cruz. (2021). Attachment 4: Core Investments - Award Recommendations by Strategic Plan. Public Records from the City of Santa Cruz. 
Clark, V., Tuffin, K., Frewin, K., \& Bowker, N. (2017). Shared housing among young adults: avoiding complications in domestic relationships. Journal of Youth Studies, 20(9), 1191-1207. https://doi-org.libaccess.sjlibrary.org/10.1080/13676261.2017.1316834

Clark, V., Tuffin, K., Bowker, N., \& Frewin, K. (2018). A fine balance: A review of shared housing among young adults. Social \& Personality Psychology Compass, 12(10). N.PAG. https://doi.org/10.1111/spc3.12415

Community Foundation Sonoma County. (2019, April 10). Create Homes Without Building. https://www.sonomacf.org/blog/creating-homes-without-building/.

County of Santa Clara. (2018, April 03). County establishes house-sharing program: high impact "without pounding a single nail". https://www.sccgov.org/sites/d5/newsmedia/Pages/HouseSharingApproval040318.aspx

County of Santa Clara, Office of the County Executive, Office of Supportive Housing. (2017, April 25). House Sharing Program Report. County of Santa Clara, Office of the County Executive, Office of Supportive Housing Legal Document.

County of Santa Clara, Office of the County Executive, Office of Supportive Housing. (2018, April 03). House Sharing Program. County of Santa Clara, Office of the County Executive, Office of Supportive Housing Legal Document.

County of Santa Clara, Social Services Agency, Department of Aging and Adult Services. (2018). 2018 Seniors Agenda Annual Report. County of Santa Clara. https://www.sccgov.org/sites/ssa/about_us/Documents/SA_AnnualReport_2018.pdf

Covia. (2015, May 15). Home Match Program Eligibility. https://covia.org/wpcontent/uploads/2021/03/Program-Eligibility_20200515.pdf.

Covia. (2021a). About. https://covia.org/programs/home-match/about/ 
Covia. (2021b). Impact \& Testimonials. https://covia.org/programs/home-match/impacttestimonials/

Covia. (2021c). Find your home. https://covia.org/services/home-match/find-your-home/ .

Covia. (2021d). Share Your Home. Covia. https://covia.org/services/home-match/share-yourhome/.

Covia. (2021e). Home Seeker Application. https://covia.org/wp-content/uploads/2021/04/HomeMatch_Seeker-Application_Fillable_20210329.pdf

Covia. (2021f). Home Provider Application. https://covia.org/wpcontent/uploads/2021/04/Home-Match_Provider-Application_Fillable_20210329.pdf

Covia. (2121g). Volunteer Job Description. https://covia.org/wpcontent/uploads/2021/01/Social-Call-Volunteer-Description-2021.pdf.

Covia Home Match Marin. (n.d.). Chamber Organizer. https://chamberorganizer.com/millvalleycc/mem_Homematchmarin.

Elder Help. (2017, October). HomeShare Program Seeker Orientation Packet. https://www.elderhelpofsandiego.org/wp-content/uploads/2017/10/HomeShare-SeekerPacket.pdf.

Elder Help. (2018a, January)._HomeShare Program Provider Orientation Package. https://www.elderhelpofsandiego.org/wp-content/uploads/2018/01/HomeShare-ProviderPacket.pdf.

Elder Help. (2018b, January). HomeShare Program Seeker Orientation Packet. https://www.elderhelpofsandiego.org/wp-content/uploads/2018/01/HomeShare-SeekerPacket.pdf. 
Elder Help. (2019a, September)__HomeShare Program Home Provider Information. https://www.elderhelpofsandiego.org/wp-content/uploads/2019/10/Home-ShareProvider-FINAL-9-19.pdf

Elder Help. (2019b, November). HomeShare Program Home Seeker Information. https://www.elderhelpofsandiego.org/wp-content/uploads/2019/11/Home-Share-Seeker11.19.pdf

Elder Help. (2021a). Who We Are? https://www.elderhelpofsandiego.org/who-we-are/history/ Elder Help. (2021b). Housing Services. https://www.elderhelpofsandiego.org/solutions-forliving/homeshare/

Fisher, K. R., Purcal, C., Jones, A., Lutz, D., Robinson, S., \& Kayess, R. (2019, May 23). What place is there for shared housing with individualized disability support? Disability and Rehabilitation. 1-9. https://doi.org/10.1080/09638288.2019.1615562

Genworth. (2019). Cost of Care Survey. https://www.genworth.com/aging-andyou/finances/cost-of-care.html

Hagopian, A., Farrow, C., \& Locke, N. (2021, February 1). Homeshare Study Policy Recommendations for the Washington State Senate Housing and Local Government Committee. University of Washington. https://depts.washington.edu/uwchips/docs/UWreport-homesharestudy2021.pdf

Hartman, M. (2018, April 15). For some minor league baseball players, wages can seem like peanuts. Market Place. https://www.marketplace.org/2018/04/05/minor-league-baseballdraws-fans-and-dispute-over-pay/

HIP Housing. (2018a). Home Sharing. https://hiphousing.org/programs/home-sharing-program/. 
HIP Housing. (2018b). Volunteering. https://hiphousing.org/how-to-help/volunteering/.

HIP Housing. (2018c). House Sharing Program. Home Sharing Program 2 - HIP Housing

Home \& Heart. (2021a). About us. https://buttecountyhomeshare.com/about-home-and-heart/. Home \& Heart. (2021b). VolunteerMatch.

https://www.volunteermatch.org/search/org1177209.jsp\#: :text=The\%20Home\%20\%26 $\% 20$ Heart\%20program\%20was, housing $\% 20$ challenges $\% 20$ in $\% 20$ Butte $\% 20$ County.

Home \& Heart. (2021c, February). Home Sharing Program Application. https://buttecountyhomeshare.com/wp-content/uploads/2021/02/HHProgram_Application-11.2020.pdf.

Home \& Heart. (2021d). What we do. https://buttecountyhomeshare.com/what-we-do/. Home \& Heart. (2021e). Home \& Heart FAQs. https://buttecountyhomeshare.com/faqs/. Home \& Heart. (2021f). Find Housing. https://buttecountyhomeshare.com/find-housing/. Home Share Vermont. (2013). A Vermonter's Guide to Homesharing. Affordable Living for the Aging. http://www.alaseniorliving.org/files/attachments/HomesharingGuide_0.pdf

Housing Authority of the City of Napa. (2018). Services Agreement (General) Napa Valley Community Housing Home Sharing Match-Up Program, January 12. Housing Authority of the City of Napa Legal Document

Kamala. (2019, July 3). HIP Housing: Frequently Asked Questions About the House Sharing Program. Everything South City. https://everythingsouthcity.com/2019/07/hip-housingfrequently-asked-questions-about-the-home-sharing-program/

Karinsky S., Szambelan S., \& Wang K. (2017, August). SPUR's Housing Agenda for San Jose Room for more. SPUR. 
https://www.spur.org/sites/default/files/publications_pdfs/SPUR_Room_for_More_print. pdf

Live Healthy Napa County. (2016, October 21). LA community summit: Housing for All in Napa County. Housing Action in Napa County Promising Efforts Underway. http://www.livehealthynapacounty.org/uploads/5/1/4/4/51449431/housing_action_bookle t_v2.pdf

Los Altos Town Crier Staff. (2019). Sharing houses: Catholic Charities, County team up for new program. Los Altos Town Crier, March 20. https://www.losaltosonline.com/specialsections2/sections/senior-lifestyles/59691-sharing-houses-catholic-charities-county-teamup-for-new-program

Los Angeles County Development Authority. (n.d.). County of Los Angeles Project Description and Activity Budget Exhibit A. Los Angeles County Development Authority Legal Document.

Maalsen, S. (2020). 'Generation Share': digitalized geographies of shared housing, Social \& Cultural Geography, 21(1), 105-113, https://doi.org/10.1080/14649365.2018.1466355

McDonald, S. (2019, October 10). Rapid Re-housing Works: What the evidence says. National Alliance to End Homelessness. https://endhomelessness.org/rapid-re-housing-worksevidence-says/

Metropolitan Transportation Commission \& Association of Bay Area Governments. (2017, July 26). Plan BayArea 2040 Final Adopted. http://files.mtc.ca.gov/library/pub/30060.pdf

Milpitas Recreation and Community Services. (2019, January-February). Senior Connection Newsletter. Case Manager's Corner. http://www.ci.milpitas.ca.gov/wpcontent/uploads/2018/12/senior-newsletter-january-february-web.pdf 
Monterey County Herald. (2016, March 19). San Jose Giants seek host families for 2016 California League season. Monterey Herald. https://www.montereyherald.com/2016/03/09/san-jose-giants-seek-host-families-for2016-california-league-season-2/

MTC \& ABAG. (July 18, 2013). Chapter 2: The Bay Area in 2040. https://mtc.ca.gov/sites/default/files/2-The_Bay_Area_In_2040.pdf

Napa Valley Community Housing. (n.d). Home Sharing. https://nvch.org/home-sharing/ Napa Valley Community Housing. (2015, September 20). Home Sharing Match-Up Program https://www.countyofnapa.org/DocumentCenter/View/967/Home-Sharing-Match-UpProgram-Information-Flyer-PDF.

Napa Valley Community Housing. (2016, August 15). Home Sharing Match-Up Program Application Checklist for Seekers. https://nvch.quickleasepro.com/d/driver?token=eyJ0eXAiOiJKV1QiLCJhbGciOiJIUzI1 NiJ9.eyJwZXJzb25faWQiOjM3MDY2NDQsImlmcmFtZSI6ZmFsc2V9.gbXA5M6grAtz25v7sM0yMa7ZvCzET1ywglDm9GiJPA.

Napa Valley Community Housing. (2020). What is Home Sharing ? https://nvch.org/wpcontent/uploads/2020/10/NVCH_HomeSharingFlyer.pdf.

National Low Income Housing Coalition. (2020). Out of reach 2020: California. https://reports.nlihc.org/oor/california

National Shared Housing. (2020). About national shared housing resource center. https://nationalsharedhousing.org/about/ 
National Shared Housing Resource Center. (2009). A Consumer's Guide to Homesharing. https://homeshare.org/wp-content/uploads/2012/04/A-Consumers-Guide-toHomesharing.pdf

Nguyen, C. (2019). Woman with muscular dystrophy gets home makeover thanks to South Bay housing advocates. ABC 7 news, July 10. https://abc7news.com/realestate/south-baygroups-work-to-prevent-displacement-amidst-housing-crisis/5388143/

Legislative Analyst's Office. (2016). Perspectives on Helping Low-income Californians Afford Housing. https://lao.ca.gov/Publications/Report/3345

SHARE Sonoma County. (2021). Icarol.info. https://www.icarol.info/ResourceView2.aspx?org=2225\&agencynum=26934773.

San Luis Obispo County. (2018). Application for Community Based Organization/Preventive Health Grant Funds Programs. San Luis Obispo County Legal Document

San Luis Obispo County. (2019). Agreement between the County of San Luis Obispo and Smart Share Housing Solution / HomeShare SLO Housing Solutions. San Luis Obispo County Legal Document

San Diego Housing Commission. (2019). San Diego Housing Commission Agreement for Shared Housing Arrangements between Older Adults and Homeless or Under-housed Individuals with Elderhelp of San Diego (Services, Materials, Supplies or Consulting under \$100,000) Contract No. HHI-20-05. San Diego Housing Commission Legal Document

Santa Clara County Board of Supervisors. (2014). Housing Element Update 2015 - 2022 adopted final.

https://www.sccgov.org/sites/dpd/docsforms/documents/healthelement_2015_adopted_fi $\underline{\text { nal.pdf }}$ 
Senior Network Service. (2020a). Senior Housing.

https://www.seniornetworkservices.org/senior-housing/.

Senior Network Service. (2020b). Volunteers Group.

http://www.seniornetworkservices.org/senior-resources-directory/volunteerorganizations/.

Shared Housing. (2017). ALA Serving seniors since 1978. http://www.alaseniorliving.org/sharedhousing.

SHARE Sonoma County. (2019a). SHARE Sonoma County Flyer. https://sharesonomacounty.org/wp-content/uploads/2019/09/SHARE-Sonoma-CountyFlyer-2019.pdf.

SHARE Sonoma County. (2019b). Stepping Stones. https://sharesonomacounty.org/wpcontent/uploads/2019/12/SHARE-Newsletter-Web-Vol2-2019.pdf.

SHARE Sonoma County. (2019c). Sharefire. https://sharesonomacounty.org/home/.

SHARE Sonoma County. (2019d). What is home sharing? https://sharesonomacounty.org/homesharing.

SHARE Sonoma County. (2019e). Home Seeker Inquiry Form. https://sharesonomacounty.org/wp-content/uploads/2020/03/Home-Seeker-Inquiry-Form2020.pdf.

SPUR. (2017). Room for More. SPUR's Housing Agenda for San Jose. https://www.spur.org/sites/default/files/2017-09/SPUR_Room_for_More_print.pdf

Smart Share Housing Solutions. (2020). Smart Share Housing Solutions Connections 2020 Annual Report 
https://www.smartsharehousingsolutions.org/_files/200001715-c7683c7687/Connections2020-Smart-Share-Housing-Solutions-Annual-Report-final.pdf

Smart Share Housing Solutions. (n.d.a). Home. https://www.smartsharehousingsolutions.org/

Smart Share Housing Solutions. (n.d.b). Is this program for me?

https://www.smartsharehousingsolutions.org/do-i-qualify/

Smart Share Housing Solutions. (n.d.c). Think About It?

https://www.smartsharehousingsolutions.org/thinking-about-it/.

Smart Share Housing Solutions. (n.d.d). Relocating?

https://www.smartsharehousingsolutions.org/relocating/.

Smart Share Housing Solutions. (n.d.e). How it works?

https://www.smartsharehousingsolutions.org/how-it-works2/.

Smart Share Housing Solutions. (n.d.f). Our screening processes.

https://www.smartsharehousingsolutions.org/our-screening-process/.

Smart Share Housing Solutions. (n.d.g). FAQ's.

https://www.smartsharehousingsolutions.org/faqs/.

Smart Share Housing Solutions. (n.d.h). Contact Us.

https://www.smartsharehousingsolutions.org/contact/.

Smart Share Housing Solutions. (n.d.i). Volunteer. https://www.vcaaa.org/about-us/volunteers/.

Smart Share Housing Solutions. (n.d.j). HomeShareSLO.

https://www.smartsharehousingsolutions.org/homeshareslo-program/ 
Smart Share Housing Solutions. (2020). Smart Share Housing Solutions Connection 2020 Annual Report. Connections-2020-Smart-Share-Housing-Solutions-Annual-Reportfinal.pdf.

Smart Share Housing Solution. (2021, March). Home Provider Application. https://www.smartsharehousingsolutions.org/_files/200001802-74aee74af0/ProviderApplication-All-HomeShareSLO-Mar-2021-fillable-draft-5.pdf.

SMC Housing Search. (2021). Shared Housing. https://smchousingsearch.org/SharedHousing.html

Smith, M.D., J.D., J. V. (2019). Fiscal Year 2019-2020 Recommended Budget. County of Santa Clara, October 27. https://www.sccgov.org/sites/opa/newsroom/Documents/recommended-budget-FY-20192020.pdf.

Sylvia, D. R., \& Sylvia, M. K. (2012). Program Planning and Evaluation for The Public Manager. Wavelland Press, Inc.

Talipova, L., Kosyakov, E., Romanovich, M., \& Lunyakov, M. (2018). Change of the functional purpose of the object through urbanistic analysis. MATEC Web Conf. 170. https://doi.org/10.1051/matecconf/201817002011

US Census Bureau. (2018, March 13). Older people projected to outnumber children for first time in U.S. history. https://www.census.gov/newsroom/press-releases/2018/cb18-41population-projections.html 
US Department of Housing and Urban Development, Office of Policy Development and Research. (2016, September 28). Home Sharing. https://www.huduser.gov/portal/casestudies/study-09282016-1.html

US Department of Housing and Urban Development, Office of Policy Development and Research. (1999). Housing Our Elders: A Report Card on the Housing Conditions and Needs of Older Americans.

https://books.google.com/books?id=aBNUXugzzZQC\&printsec=frontcover $\&$ source=gbs ge_summary_r\&cad=0\#v=onepage \&q\&f=false

US Department of Housing and Urban Development. (2021). FY 2021 Fair Market Rent Documentation System. [Data Sets]. https://www.huduser.gov/portal/datasets/fmr/fmrs/FY2021_code/2021summary.odn

US Department of Housing and Urban Development. (2014). Rental Burdens: Rethinking Affordability Measure. https://www.huduser.gov/portal/pdredge/pdr_edge_featd_article_092214.html\#: :text=H UD\%20defines $\% 20$ cost $\% 2$ Dburdened $\% 20$ families, of $\% 20$ one's $\% 20$ income $\% 20$ on $\% 20$ re $\underline{\mathrm{nt}}$

Ventura County Area Agency on Aging. (2016). Home Share Information Booklet. https://s29358.pcdn.co/wp-con10t/uploads/HomeShareInformationBooklet.pdf.

Ventura County Area Agency on Aging. (2021). Home Provider Online Application. https://www.vcaaa.org/home-provider-online-application/ 
Von Kaenel, C. (2020, May 28). New home-sharing nonprofit matches older adults, students, Camp Fire survivors. Enterprise-Record. https://www.chicoer.com/2020/05/28/newhome-sharing-nonprofit-matches-older-adults-students-camp-fire-survivors/

Wilkinson, E. \& Ortega-Alcazar, I. (2019). Stranger Danger? The Intersectional impacts of shared housing on young people's health \& wellbeing. Health and Place. 60. 102191102191. https://doi.org/10.1016/j.healthplace.2019.102191

Yerena, A. (2019). Book Review of Small is Necessary: Shared Living on a Shared Planet: by Nelson, A., London: Pluto Press, 2018. Housing Studies. 34(2). 384-385. https://doi.org/10.1080/02673037.2019.1558591 